\title{
Sex Ambiguity in Early Modern Common Law (1629-1787)
}

\author{
Maayan Sudai
}

Prior to the modern understanding of sex as fundamentally biological, a person's sex status - that is, whether they were male or female - was largely a legal issue. How was this legal fact established in cases of doubt? To answer that question, this article tells the story of the regulation of cases of doubtful sex (the cases of people who were then referred to as hermaphrodites) between 1629 and 1787 in England and Colonial America. Trials of doubtful sex from this period show that, rather than being based on a single piece of evidence (such as genital appearance), determining a person's sex required a rich and contextsensitive evaluation by witnesses and juries. However, toward the end of the eighteenth century, scientific and medical authorities gradually sought to classify hermaphrodites according to their "true sex" and to remove any doubt from that classification. Ultimately, this article demonstrates that the early modern common law tradition did not conceptualize sex as purely binary and did not hinge on medical opinions throughout most of the eighteenth century. These findings highlight the continuous engagement of courts in actively shaping the meaning and ontology of sex rather than merely reflecting it in their decisions.

\section{INTRODUCTION}

In the early modern period, being male or female was a fundamental legal status. In the legal apparatus of the time, a person's sex had tremendous material and political implications for their rights and responsibilities. These implications extended throughout various fields of law: property ownership, inheritance, capacity to contract, marriage and domestic relations, legal procedure, criminal culpability, enfranchisement, and so on (Langley and Fox 1994, 1-10; VanBurkleo 2001, 9-16). As a result, legal authorities were at times called upon to determine an individual's sex.

\footnotetext{
Maayan Sudai is Assistant Professor, Faculty of Law and Faculty of Humanities, University of Haifa, Israel Email: smaayan@univ.haifa.ac.il

I would like to thank Janet E. Halley, I. Glenn Cohen, Sarah S. Richardson, Sheila Jasnoff, Anna Lvovsky, David S. Jones, Tal Golan, Binyamin Blum, Elizabeth Reis, Lihi Yona, Michael A. Stein, Shira Shmuely, Orna Alyagon Darr, Sagit Mor, Yair Sagi, Ely Aaronson, Hila Shamir, Yishai Blank, Aeyal Gross, Shai lavi, Roy Kreitner, Oren Harman, Ido Katri, Michelle Spektor, Jonathan Yovel, Tammy Harel Ben-Shahar, Itamar Mann, Libby Adler, Noya Rimalt, Sara Cohen Shabot, Yechiel M. Barilan, Fady Khoury, Reut Cohen-Ojalvo, Doron Dorfman, Oren Tamir, Regina Larrea Maccise, Gali Racabi and Shelly Simana for thoughtful comments, suggestions, and insights. Earlier drafts of this article benefited from the comments of participants in seminars held at Harvard Science, Technology and Society circle in 2018, Bar Ilan University Science, Technology and Society colloquium in 2018, and Tel Aviv University Bioethics and Law seminar in 2018. A special thank you to Yuval Moscovitz, and to the anonymous reviewers for their deeply engaging and constructive comments. This research was supported by the ISRAEL SCIENCE FOUNDATION (grant No. 704/21).
} 
Determination of sex for individuals was not an issue that troubled legal authorities often. Nevertheless, in some cases, not terribly common but also not so rare, sex did not declare itself at birth but, rather, puzzled viewers such as family members, neighbors, employers, midwives, and doctors. People with unclear sex were legally referred to by the Latin term "hermaphrodite" (Dreger 1998, 31-32; Oxford English Dictionary Online, n.d.b). ${ }^{1}$ Scholars working on the history of hermaphrodites often cite the classical legal formula, shared by several legal systems from at least the thirteenth century, that resolved sex ambiguity using a theory of dominancy-that is, asking which sex (male or female) is more prevalent in the individual.

This understanding of sex correlated with the Hippocratic/Galenic one-sex model, which conceptualized females as "underdeveloped males" who "lack vital heat" (Laqueur 1992, 4; R. Gilbert 2002, 36). Historian and sexologist Thomas Laqueur $(1992,135)$ noted that sex was a sort of "shaky foundation" that could change through time and place and that genitals were indicative but not determinative. Because sex was considered to be an unstable trait at the time, courts and magistrates tried "maintaining clear social boundaries, maintaining the categories of gender" (135; emphasis added). Doing so was crucial for social order. As historians of women and of intersex people recognized, the differentiation between males and females was essential and instrumental to maintaining the political distinctions between men and women. In fact, the growing separation between them in early modern English political life was accompanied by a surge in legal writing about hermaphrodites in the eighteenth century. In this article, I discuss a body of such early modern legal treatises on hermaphrodites_-some examined for the first time-to suggest that legal writing about hermaphrodites in that century represented an impulse to clearly delineate the male-female boundary in multiple areas of law and was likely fueled by a desire to ingrain a separation between males and females in more legal spheres.

Although treatise writers offered an explication of the law on hermaphrodites, it was courts and justices that actually listened to testimonies, viewed evidence, and made factual determinations about an individual's sex, and such judicial classifications are the focus of this article. Its main argument is that, in the early modern period, the common law practice was to defer to commonsense classifications of sex and not to medical classifications, as was customary at the time in continental Europe. Specifically, I show that in eighteenth-century England, courts that classified hermaphrodites did so by relying on lay witnesses and not on the testimonies of doctors or physicians, despite their increasing authority in scientific circles and popular venues outside the court in

1. A note on terminology: today, people with unclear sex are referred to using terms such as intersex or people with differences of sex development (DSD), depending on the context. See Lundberg, Hegarty, and Roen 2018; Sudai 2018. Although some reclaim the historical term "hermaphrodite," many others consider it to be anachronistic and derogatory. See Intersex Society of North America, n.d. I recognize the problematic connotations of this term and therefore will generally use the term "intersex" to describe people with unclear sex; I will, however, use "hermaphrodites" or "doubtful sex" where I describe historical events or references. With respect to the individuals whose trials are examined, I will refer to them by their names when possible and will use pronouns according to the way they presented themselves. When unclear, I use the pronoun "their." Additionally, it should be noted that the use of the term "hermaphrodite" by both lay person and experts was not uniform throughout periods and discourses and could signify various instances of gender transgressions, not just cases in which an individual's sexual organs did not conform to social expectations in various ways. 
England. I attribute this difference to the relatively late bloom of medical jurisprudence in England compared to that in continental Europe. I further suggest that, from the mideighteenth century onwards, justices gradually began to believe that the commons were unfit to classify hermaphrodites, and, as a result, they aspired to facilitate an "enlightened" and professional legal process to prove sex. This aspiration, documented in the late eighteenth century, eventually led to the diminishment of lay knowledge in sex classification in common law and to a conceptual transformation in the legal meaning of sex-from a "shaky" continuum to a binary.

My analysis is based on close readings of new primary and secondary sources related to several trials involving hermaphrodites. Central to this analysis are six trial records related to four people who were suspected of being hermaphrodites in England and Colonial America between 1629 and 1787. Two of the trials-those of Constantia Boon and Betty John - are explored in this work for the first time, as far as I am aware. Thomas/ine Hall and Chevalier d'Eon have already been the subjects of much scholarly interest, but they have been explored outside the legal field. ${ }^{2}$ D'Eon's trials, in particular, have not been examined, to the best of my knowledge; Hall's trial, in contrast, has been closely analyzed in works of historians of early America who stressed the crucial role of community members in sex determination in this time and place (Vaughan 1978, 146-48; Brown 1995, 171-93; M. Norton 1997; Reis 2009). My analysis will build on these works from a legal perspective, and then it will shift to focusing on my own examination of other trials conducted in common law courts. My readings of these cases are supplemented with new primary sources, such as dictionaries and pamphlets published in that time frame (1629-1787). They are also supplemented by canonic histories of intersex people in North America and Europe by Elizabeth Reis, Alice Dreger, Greetje Mak, Lorraine Daston, Katharine Park, and Anne FaustoSterling, which have largely explored the medical and cultural history of hermaphrodites in early modern times and until today (Daston and Park 1998; Dreger 1998; Fausto-Sterling 2000; Reis 2009; Mak 2013). By contributing a robust legal perspective to these works, this article helps identify and illustrate the special role that law and legal procedure played in major documented developments of the time, such as the rise of the concept of "true sex" and the rise of medical jurisdiction over hermaphroditic bodies in Europe and early America. Attending to the differences between legal systems in England and continental Europe also helps uncover the way in which early modern common law conceptualized sex at the time.

The particular history of sex classification in early modern common law is important for several reasons. First, it implies a strong relationship between the legal procedure of proving sex and the ontology of sex itself. Laqueur's $(1992,8)$ important argument was that, in the early modern period, sex was a sociological, rather than an ontological, category. Accordingly, this article examines the relationship between the ontology of sex and the legal procedure of proof. It demonstrates how judges acted as epistemic gatekeepers to support the transformation of sex from one kind of category to another and shaped the meaning and content of sex by managing evidence and

2. D'Eon's bold, flamboyant, and well-recorded public personality made him/her a fascinating subject of contemporary scholarly research for historians and researchers of sex and gender. See, for example, Clark 1998, 36; Burrows et al. 2010, 45-51. 
witnesses. Legal scholars such as Ariela J. Gross (2009) and Ian Haney-López (2006) have done similar work to explore how legal procedure in courts constructed whiteness or non-whiteness in cases of doubt, but no such work has been done regarding doubtful sex. Thus, joining existing scholarship on the legal construction of race, this article demonstrates the constitutive character of evidentiary legal procedure in creating categories of identity and personhood.

Second, the history of judicial classifications of doubtful sex in early modern common law offers insights into the conceptual sex/gender divide. The particular history of sex classification in common law provides relevant historical context for the ongoing debate about the meaning of sex in US jurisprudence and, specifically, for whether the term "sex" refers to reproductive organs or also includes cultural and social attributes, usually termed "gender." This article demonstrates that the legal fact of sex in early modern common law was neither exclusively corporeal nor exclusively behavioral or social-it was a mixture of these attributes, molded into a judicial decision-and this practice was bound up with common law's core philosophy of trusting common sense. The cases presented here thus provide a unique and revealing perspective on how sex and sex ambiguity were conceptualized, regulated, and controlled in a pre-scientific legal context before the modern conceptual separation between sex and gender took hold.

Third, the article stresses the particular role of law in facilitating the social acceptance of the Aristotelian model that denied the existence of hermaphrodites and stated that "men and women were unequivocally different categories" and the ideal of "true sex" (R. Gilbert 2002, 36-40). ${ }^{3}$ Although celebrated writers such as Laqueur (1992) and Michel Foucault (1988) have historicized the dramatic transformation in the meaning of sex, their works encompass a range of cultural, religious, and medical-but not so legal-institutions. This article builds on their work by using historical legal treatises and trial cases to illustrate how the legal institution contributed to the process of constructing sex and gender in early modern times. I argue that justices wanted to detach themselves and the court from "fables" about hermaphrodites and that they aspired to facilitate a modest and professionalized judicial classification process. These changes not only impacted the lives of intersex people considerably but also had dramatic consequences for thinking about sex in the long run-mainly, the idea that sex classification is fundamentally a scientific endeavor and not a legal one.

\section{HERMAPHRODITES AND LEGAL MONSTERS}

"Hermaphrodite" is an ancient term, historically used to describe someone possessing both male and female anatomical characteristics from birth. Hermaphrodites were culturally and legally associated with the notion of "monsters," which was a label used for babies born with abnormalities so severe as to undermine the baby's status as a human being (Daston and Park 1998, 173; Reis 2009, 23). According to Foucault (1980), a monster in this sense is a "juridico-biological" problem. As an exceptional

3. Elizabeth Reis (2009) historicized the shift to searching hermaphrodites' true sex in medical discourses in the United States. Alice Dreger $(1998,80-88)$ traces a similar search for true sex or the fear of classifying hermaphrodites to a mistaken sex in medical discourse in Europe. 
deviation from the general species, such a person disturbed the regular application of rights and duties and presented a "double breach" — that is, they violated both the laws of nature and the laws of men and combined the impossible with the forbidden (Daston and Park 1998; Sharpe 2010). The hermaphrodite, then, was a particularly intriguing type of monster for jurists.

The legal category of monsters entered English law in the thirteenth century and was historically associated with the legal category of hermaphrodites as both appeared and disappeared from English law at approximately the same time (Sharpe 2009). ${ }^{4}$ English jurists described "monsters" as possessing severely deformed bodies or being in the shape of "beasts" (106). The essential purpose of this legal category was to discern who was a legal person and who was not. For example, according to the law, "monsters" could not inherit land. If there was no successor other than a legal monster, then the land was handed over to the lord (Blackstone 1753, 247). The legal category thus identified those who fell outside the borders of humanity and of law. ${ }^{5}$ English law's definition of hermaphrodites appeared in proximity to the legal category of monsters in the thirteenth century. The English jurist and justice Henry de Bracton (1968; n.d.), who wrote one of the most fundamental treatises of English law, On the Laws and Customs of England, introduced a definition of "hermaphrodite" right after the category of monsters. He cited Roman law authorities, saying: "Mankind may also be classified in another way: male, female, or hermaphrodite. Women differ from men in many respects, for their position is inferior to that of men" (Bracton 1968, 31) and that "[a] hermaphrodite is classed with male or female according to the predominance of the sexual organs" (Sharpe 2009, 105). ${ }^{6}$

Despite the cultural and legal proximity of hermaphrodites to monsters, however, hermaphrodites were never considered legal monsters. Instead, they maintained a separate human status_one between males and females (Sharpe 2009, 101-2). Bracton's definition of hermaphrodites was cited four centuries later by renowned English jurist and justice Sir Edward Coke (1979, 7.B), in his classic book Institutes of the Laws of England (1628). The book provided a comprehensive and updated description of common law, which referred to hermaphrodites as having indeterminant sex: "Every Heire is either a male or female. And an hermaphrodite, that is both male and female. And an hermaphrodite (which is also called Androgynus) shall be heire, either as male or female.... And accordingly it ought to be baptized.... An hermaphrodite may purchase according to that sexe which prevaileth" (3.A, 7.B). ${ }^{7}$

4. As this article details, both concepts appeared in English law in the thirteenth century. The concept of "monsters" was finally removed from English law in a case from 2000 after the judge said this expression is "redolent of superstitious horror" (see Sharpe 2010,1). From the nineteenth century onwards, the legal concept of hermaphrodites and the dominancy rule similarly became a sort of myth or relic of a backward state of reason, as noted in modern legal dictionaries in entries for Hermaphrodites. See, for example, Wharton (1987, 295), who describes hermaphrodites as ancient "fables" and that "researches of modern anatomists have completely set at rest the long-debated question of hermaphrodism, in the vulgar acceptation of the word. It is anatomically and physiologically impossible."

5. Coke 1853, Part L.1.C.1.S.1: "A monster, which hath not the shape of mankind, cannot be heire or inherit any land, albeit it be brought forth within marriage;[a] but although he hath deformity in any part of his body, yet if he hath human shape he may be heire."

6. For a later English translation of Bracton on hermaphrodites, see Bracton and Twiss 2012, 35.

7. In classic common law treatises, "purchase" means the capacity to be an owner of land, not through descent. See Oxford English Dictionary Online, n.d.d; see also Coke 1853, clxxxviii. 
Bracton's and Coke's earliest references to the category of hermaphrodites in English law are revealing for their mundane treatment of sex ambiguity. Despite the cultural association of hermaphrodites with monstrosity as a symbol of "divine wrath" (Daston and Park 1998, 176; Sharpe 2009, 111), it seems that throughout the long, clearly multifaceted period stretching from the thirteenth century to the eighteenth century, hermaphrodites were associated with a benign meaning of monstrosity that also existed at that time-a sort of "ornament" of nature that evoked sensations of pleasure and curiosity (Daston and Park 1998, 177). ${ }^{8}$ For example, Jacob Giles (1718, n.p.), a prolific English legal writer on common law who published in 1718 the Treatise of Hermaphrodites and described hermaphrodites as "wonderful" secrets of nature and "curious discoveries." As this article will demonstrate, legal treatises and case law from early modern times consistently identified hermaphrodites as part of humankind and not as supernatural or subhuman monsters (Sharpe 2009, 130). ${ }^{9}$ They were human, and, therefore, they could inherit property and engage in other legal actions; however, they had to do so as either males or females.

\section{A TOUCHSTONE FOR MALE-FEMALE POWER STRUGGLES}

Alongside the cultural recognition of the fundamental humanity of hermaphrodites grew a practical legal approach regarding how they ought to be regulated in the civil sphere with respect to their sex. Bracton and Coke's definitions of hermaphrodites, and their later instantiations, required that such people be treated according to the most dominant sex-either male or female. This dominancy model implied that the legal approach of common law conceived sex to be a relative position between two poles rather than a pure dichotomy. That is, the assignment of hermaphrodites to one of the two recognized sexes lacked the modern notion of "true sex" that supposedly lies within any individual and needs to be revealed and declared. ${ }^{10}$ Rather, Bracton and Coke's definitions described hermaphrodites as either possessing an intermediate position between male or female or as possessing elements of "both," though they still expected hermaphrodites to be "sexed" to either male or female. ${ }^{11}$ In Treatise of Hermaphrodites, Giles (1718, n.p.) also described hermaphrodites as "a mixture of both Sexes, and to both incompleat [sic]."

Despite such legal recognition of a state of sex indeterminacy, however, a condition of sexual ambiguity was not sustainable in the law. As Foucault (1998) has pointed out, sex ambiguity disturbed the peaceful application of the law and the assignment of

8. Lorraine Daston and Katharine Park (1998) produced one of the most celebrated histories on the wonders of nature and naturalists in pre- and early modern Europe and devoted a special chapter in their book to the subject of hermaphrodites.

9. Daston and Park $(1998,187)$ emphasized that the benign, naturalized meaning of monsters was not necessarily a product of eighteenth-century enlightenment, humanism, and the emergence of science and rational thought but, rather, that it had already existed in thirteenth-century writings of medical and natural philosophers.

10. Michel Foucault $(1980,7-17)$ historicized the appearance of the "true-sex" theory in eighteenthcentury Europe.

11. Coke's understanding of hermaphrodites as possessing "both sexes" was occasionally made in legal texts and dictionaries. A legal dictionary from 1754 defined a hermaphrodite as a "person of both sexes, or who has the parts of generation both of male and female." See Society of Gentlemen 1754, 1:1611. 
rights and duties to individuals. Because the common law system (like many others) differentiated between males and females in significant ways, various treatises and expositions of the law attempted to clarify and regulate hermaphrodites' ability to engage in different sex-restricted legal actions. Against the ambiguity of sex in hermaphrodites, treatise writers reacted with solidifying male-female distinctions in the law. For example, the constitutive definition of hermaphrodites in English law was intrinsically affiliated with their capacity to be heirs. This is because in medieval England, women's capacity to succeed was vastly restricted. Land was usually passed to the eldest son according to the practice of primogeniture. Some of these practices continued into the early modern period as well (Blackstone 1753, 902). Carole Shammas (1987, 150) notes that in the English inheritance system "one son usually inherited a disproportionately large share of an estate." The classification of hermaphrodites as males or females could therefore have significant capital consequences, and legal treatises attempted to regulate those. English jurist John Godolphin $(1701,387)$ stated in 1701 that if a mother gives birth to a hermaphrodite child, then the child is to accept a portion according to the sex most likely to be assumed. However, if "that is also doubtful, it is presumed according to the more worthy Sex, viz. Masculine."

For the purpose of criminal appeals, because women were not able to appeal (except in the case of certain events, like the murder of a husband or ancestor), ${ }^{12}$ legal writer and judge John Comyns (1762) stated in his 1762 Digest of the Laws of England that "the heir who brings the Appeal must be a male. ... Or, an Hermaphrodite, if the Male Sex be predominant; otherwise, not"13 (W. J. 1710; Giles 1719, 5; Macnair 2004). In the field of contracts, a person's sex was also legally significant. The English legal writer William Sheppard $(1656,188)$ explains: "An Hermaphrodite may give or grant, take or purchase as another person may do; according to that sex which prevaileth."14 Here again, hermaphrodites were fit to engage in certain types of contractual actions, but their sex status carried significant financial consequences. For example, under the doctrine of coverture, a husband and wife were considered to be one person, which meant that a married woman's legal being was subsumed by her husband's and, therefore, her contractual engagements were void (Zaher 2002, 460-61). ${ }^{15}$ If a hermaphrodite person was married, their classification to one sex or the other would thus determine the validity of the person's contractual engagements.

The intensive legal attention given to the relatively uncommon subject of hermaphrodites by treatise writers in the eighteenth century alludes to the legal commitment to protecting male privileges as defined by the separate-spheres ideology of the time. According to Mary Beth Norton $(2011,4)$, it was during this time that Anglo-American society ascribed females with activities located in the household, whereas males were designated for positions in the political sphere of governance.

12. "Appeal" in this case means a private accusation of a murderer by a person who was related to the party killed. See Giles 1719. 223).

13. This rule was also mentioned in the writing of social reformer Edward Augustus Kendall (1818,

14. Likely quoting Coke (1853). For Sheppard's biography, see Matthews (2008). For another treaty mentioning the rule, see Comyns 1762, 3.

15. See Blackstone 1753, 442: "Every legal being or legal existence of the woman is suspended during the marriage: under whose wing, protection, and cover, she performs every thing." 
Protecting and enhancing male privileges went hand in hand with ascribing these differences in the body. From this perspective, treatise writers can be seen as guarding legal privileges (such as engaging in contracts, inheriting land, or bringing a criminal appeal) against being used by non-males or by individuals whose maleness was in doubt. Not for the first time, the treatment of hermaphroditic bodies and discourse about them represents an impulse to clearly delineate a male-female boundary as a way to enforce the political status quo between them.

\section{THE COMMONSENSICAL APPROACH TO SEX IN COMMON LAW}

Legal recognition of sex ambiguity and the accompanying legal commitment to classifying hermaphrodites as male or female are not unique to common law. Roman law, for example, also interpreted sex as a matter of dominancy and as a relative status; these views served as a source of authority for Bracton's (1968) thirteenth-century definition of hermaphrodites (Nederman and True 1996, 511-15; Iacub 2009, 2763; Sharpe 2009, 105-7). ${ }^{16}$ Nevertheless, common law's approach to hermaphrodites and to sex was unique in its method of proving sex. Whereas civil legal systems relied on specialized and medical opinions of sex in the process of legal sex classification, Anglo-American case law concerning intersex people related somewhat differently to medical authorities in such matters. That is, rather than relying on such expert opinions, common law valorized commonsense wisdom to determine sex. Daniel Boorstin (1996, 113) notes that common law was "nothing else but custom, arising from the universal agreement of the whole community." 17 Thus, as the cases presented later in this section will show, physicians, surgeons, and natural philosophers in both England and in the English colonies in America were afforded no special privilege over the community in the legal classification of sex, despite their rising authority to examine hermaphrodites outside the courtroom. ${ }^{18}$ Judicial classifications of doubtful sex cases simply rested on commonsensical understandings of sex.

As a result, common law's method of deciding which sex a person should occupy for legal purposes was not particularly structured or formalized. According to the rule of dominancy, common law expected intersex people to be assigned to one sex or the other based on the predominance of parts, the evidence for which could be rather arbitrary, intuitive, and unconfined. One striking example of such evidence is found in Giles's (1718, n.p.) Treatise of Hermaphrodites, where he advises classifiers to examine features that range from body hair to bravery and pleasantness: "A person that is bold and sprightly, having a strong voice, much hair on the body, particularly on the chin and privy parts ... are certain demonstrations that the hermaphrodite has the privy parts of a man in a more predominant manner than those of the other sex." Similarly, he writes that if a hermaphrodite "has good breasts, skin smooth and soft ... if there be a sparkling and agreeableness in the eyes ... and if the vagina

16. Talmudic and other religious legal codes are most likely the origin of these rules. See FaustoSterling 2000, 33; Reis 2009, 11. For an example of Jewish law of hermaphrodites, see Cohen 1999.

17. Citing from Blackstone 1753, 471.

18. For more about contemporary legal reliance on medical jurisdiction to govern intersex people, see Garland and Travis 2020. 
is not too defective, such an hermaphrodite ought to pass for a woman" (n.p.). I argue that such lack of formal methodology in the prevailing sex model and accompanying legal treatises left much to the discretion of judges, who, according to the common law tradition, gave weight to community opinions and the knowledge of lay witnesses and juries.

A paradigmatic example of the centrality of such commonsense knowledge is the case of a servant named Thomas/ine Hall, who in 1627 arrived in Warrosquyoacke, a small English settlement in Colonial Virginia (Brown 1995, 176). The townspeople there questioned Hall's sex. In 1629, after investigating the matter and failing to reach a final classification, they brought Hall to the General Court at Jamestown to determine Hall's sex and guilt in the charge of fornication. Found in a modern reprint of the minutes of the Council and General Court of Colonial Virginia, the testimonies portrayed in the court transcript reveal the various examinations conducted by the townspeople before arriving to court.

Historians such as Kathleen Brown, Mary Beth Norton, Alden Vaughan, and Elizabeth Reis have analyzed these testimonies to determine how such a town resolved issues of sex/gender ambiguity, and they found that the town's investigators used two methods to determine Hall's sex: the first was to question Hall and the second was to examine Hall's body. One witness, for example, Francis England said that he "felt" Hall and pulled out Hall's "members"-likely their male genitals_-which made him believe that Hall was a "perfect man" (McILwaine 1924, 194; Oxford English Dictionary Online, n.d.c). The most thorough physical investigation was conducted by a group of married women who examined Hall's naked body several times and concluded that Hall was a male. The chief questioning, however, was conducted by plantation commander Captain Bass, who asked Hall to self-identity as a man or woman. Hall replied that they were both and that they had not made use of the male parts, described as an inch-long piece of flesh (McILwaine 1924, 195).

When the case finally arrived in court, the judge-Governor Pott, who was also trained as a medical doctor-relied on communal knowledge through witnesses' testimonies and did not initiate his own physical investigation. The court listened to Hall, who provided their life narrative. Hall testified to be born in England and baptized as a girl named Thomasine. At the age of twelve, Hall was sent to an aunt in London and then lived there for 10 more years, until Hall's brother was drafted into the army. Hall testified to cutting their own hair, assuming male attire, and joining the English armed forces as a male soldier serving in France. Upon returning to England, Hall again presented as a woman and did needlework up until 1627, at which point decided to embark on a journey to the English settlement of Virginia and work as a male servant (Brown 1995, 180).

After listening to testimonies, Governor Pott did not reach a conclusive sex classification; rather, he mandated that Hall add feminine accessories to his male apparel, likely to publicly signal his hybridity (McILwaine 1924, 195). ${ }^{19}$ This punishment was a significant deviation from the common law rule, which basically forced a male or female classification on people with doubtful sex, and scholars interested in Hall's case

19. He also decided that Hall should appear in quarter court showing guarantees for his good behavior, until the court discharged Hall. 
attempted to understand what drove this change. Kathleen Brown (1995, 188-90) has suggested that Hall's punishment reflects the court's interest in addressing the colony's need for workers, which led it to avoid corporal punishment and ignore the charge of fornication. Mary Beth Norton (1997, 60), however, suggests that the townspeople were already firmly convinced of their own varied views regarding Hall's sex and that any declaration by the court that affirmed one or the other was impossible, considering what was already known through oral and physical investigations of Hall. The court accordingly solved the clash by creating a singular category of sex for Hall.

A third possible explanation could be that in colonial America principles and doctrines from English law were largely applied based on the memory of local justices. That is, judges enforced a combination of what they remembered from English law and local practices and legislation, both of which could differ significantly from the original rule (Nelson 2008, 1:40-41). Considering that the extensive legal writing about hermaphrodites in treatises began slightly later and was produced mainly during the eighteenth century, it could be that Pott simply was not aware of the rule that required classifying hermaphrodites according to their most "dominant" sex.

Hall's case also illustrates how local authorities balanced corporal and behavioral evidence to determine sex. The townspeople who attempted to establish Hall's sex status repeatedly looked at Hall's body, felt it, and questioned Hall, but they could not agree upon any final classification. Brown $(1995,173)$ suggests that the instability of sex differences was partly due to lack of "a coherent biological foundation for sex." Mary Beth Norton $(1997,64)$, on the other hand, argues that, in the process of communal reasoning, the body, and, particularly, the ability to consummate a marriage, were more important than Hall's feminine gender. I agree with Norton that the body, and sexual organs, in particular, were an important factor to calculate; however, I suggest that fact makers in courts presented a fluctuating balance between corporal and behavioral indications. More cases reveal that gender served a critical function, along with the courts' wish to restore social order regarding sexual norms, as Norton also indicated.

This article's main contribution is that it draws connections between the centrality of the body, the structure of the legal procedure of proof, and the distribution of epistemic authority within it. I argue that the reliance of eighteenth-century common law on the opinions of community members to classify hermaphrodites contributed to rich understandings of sex that were not reduced to pure anatomy. Because the community's understanding of sex was prioritized over medical opinions about it, sex classifications leaned on lay interpretations of body anatomy and, not less important, on the social interactions with the individual and the degree to which their behavior aligned with gender norms and stereotypes of the time. ${ }^{20}$ This understanding clarifies that when a court seeks to understand if sex is more about biology or about behavior, the answer lies partly in the structure of the legal procedure. Accordingly, this article contributes

20. This is not to imply that medical classifications of hermaphrodites were purely anatomical, particularly in early modern times, when the nineteenth-century scientific theory to classify hermaphrodites had not yet been developed. Medical classifications of hermaphrodites in civil law and later in common law were not successful at distinguishing between the body and its social context. However, unlike communal investigations, medical investigations included a thorough physical examination that served as the source of their authority. See Mak 2013, 114-15. 
to the conversation about the relationship between sex and gender for the purpose of legal classification of sex, advancing the view that the hierarchy of prioritizing sex over gender derives from changes in the legal procedure of proof.

To make the argument that common law judges in eighteenth-century England relied on communal knowledge when making sex classifications, I will review the legal cases of three individuals with doubtful sex from that period. These cases demonstrate that witnesses and juries relied on a mixture of social and physical elements, such as body structure, strength, baptismal name, life chronology, general mannerisms, and sometimes even external interests (such as political or professional prestige) in determining an individual's sex. The gradually increasing epistemic force of medical and scientific accounts of intersex people appear in the background of these court cases, but they do not take hold inside the courtroom-yet. By the late eighteenth century, however, judicial quandaries regarding who and what to trust when determining sex reveal a general perplexity, surrender to specialized evidence, and a growing enchantment with a supposedly doubt-free culture of proof, leading to the acceptance of the true-sex paradigm.

\section{Constantia Boon (1719): The Wisdom of Lay Juries}

By the early eighteenth century, English physicians, anatomists, and philosophers of nature were already showing interest in intersex people and were attempting to view them as part of nature and classify them as either males or females. However, as exhibited in Hall's case and in the other cases that will be presented, medical experts were not yet treated as privileged witnesses inside the court when adjudicating people's sex. Rather, at least through the end of the eighteenth century, courts appointed juries and invited lay witnesses in order to classify intersex people.

Such was the case of Constantia Boon, the famous hermaphrodite of Charing Cross. English physicians had become important validators and refuters of hermaphroditism in non-legal settings, and they published accounts and detailed descriptions of hermaphrodites who displayed themselves in public shows (Guerrini 2016, 28). Advertisements inviting the public to view the spectacle prided themselves on receiving medical authentication: "There is now to be seen the greatest wonder in nature, being an hermaphrodite, aged 18 years, complete male and female. And has given a general satisfaction to the most ingenious physicians and surgeons, who have inspected and confirmed the same" (The Post Man, and the Historical Account 1714). The credentialed hermaphrodite publicized in this ad was Constantia Boon, who was presented to the English public in London and elsewhere around 1714 (see Figure 1).

Physician and anatomist James Douglas, who believed that intersex people were actually "deformed" women, examined Boon in detail and delivered his account to the Royal Society of London in 1715 (Guerrini 2016, 31). ${ }^{21}$ Douglas reported that Boon was born in Deptford in 1697 and was trained to be a quilter by the name of Constant or Constantia. Her mistress observed something unusual and ordered Boon

21. Douglas's 1715 manuscript was not published in print but only delivered to the society. His illustrations were published in 1722. See Cheselden 1722, 319-22. 


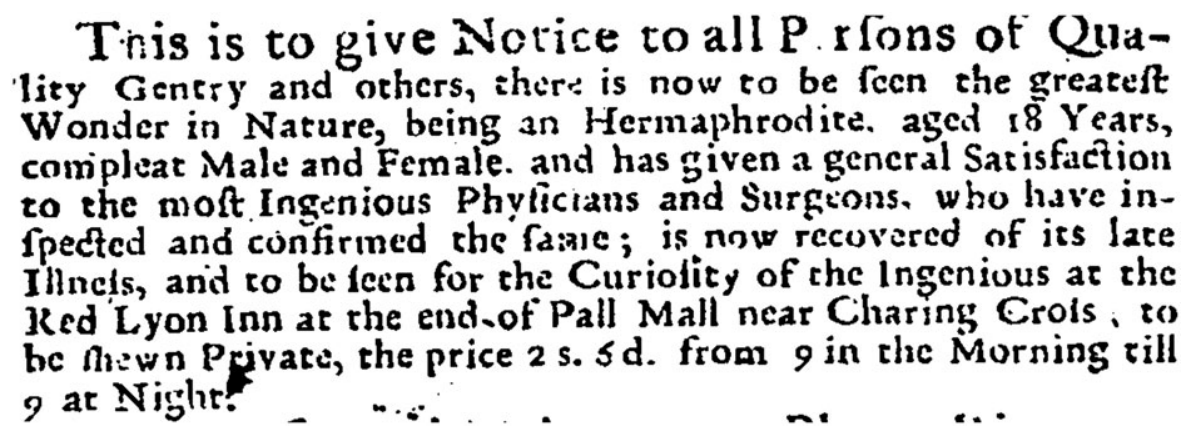

Figure 1.

Advertisement for the viewing of Constantia Boon in Post Man and the Historical Account, London, December 4, 1714. Credit: Public domain.

to be examined by an old woman, who immediately declared Boon to be a hermaphrodite. Boon's mistress decided to present Boon as a "prodigy of nature" in Smithfield. According to Anita Guerrini (2016, 35), who examined the medical inspection of, and experimentation on, hermaphrodites in eighteenth-century England, Boon was a popular "high-end" exhibit-she demanded relatively high admission fees and traveled from venue to venue all the way to London. When Douglas examined Boon, he asked questions about her menstrual cycle and sexual preferences and then examined her genitals closely and invasively through vision, touch, and probing with instruments. Douglas detailed the shape and structure of Boon's labia, clitoris, and vagina, contrasting them with the size and shape of a penis, scrotum, testicles, and urethra. Douglas concluded that Constantia was not a true hermaphrodite, as she did not have a double-sex set of functioning organs but was instead "a real woman with the addition of something extraordinary in her labia" (Guerrini 2016, 42).

Douglas's verdict that Boon — a validated, displayed hermaphrodite — was in fact or "really" a deformed woman and not a hermaphrodite was later repeated by other physicians with regard to other publicly displayed hermaphrodites. ${ }^{22}$ According to Guerrini, public displays of hermaphrodites like Boon served as a space for the meeting of learned and popular curiosities. In these contexts, she says, physicians worked to create a hegemonic narrative of hermaphrodites by producing naturalistic descriptions, accompanied by illustrations and learned observations, that classified them to either sex (49). Despite these efforts, however, the capacity of such physicians to shape popular and even professional conceptions of hermaphrodites was limited, as the public and other professionals maintained the belief that true hermaphrodites can exist (50).

Four years after Douglas delivered his report to the Royal Society, a trial involving Boon offered new evidence that medical and scientific knowledge had not yet affected the adjudication of intersex people in court. Indeed, this trial serves as another case of judicial reliance on communal knowledge and its reliance on non-physical elements. Specifically, on September 3, 1719, the Old-Baily Court in London confronted the question of Boon's sex when a woman named Katherine Jones was accused of bigamy.

22. See the writings of James Parsons $(1741,1751)$ (Douglas's protégé), which make the same argument about the "Angolan Woman" displayed as a hermaphrodite. 
According to the court record, Jones married Boon in April 1719 at a private house in Blue Ball Alley, but she was already married to a man named John Rowland (Tyburn Chronicle 1768). ${ }^{23}$ Remarkably, Jones tried dodging the accusation of bigamy by confessing to either marrying a "monster" or possibly a woman. That is, Jones acknowledged the two marriages, but she argued in her defense that Boon "was no Man, and therefore could not be a Husband; that it was a Monster, a Hermaphrodite, and had been shown as such at Southwark-Fair, Smithfield, and several other Places."

To support her claim, some witnesses were called to court, one attesting that he knew Boon's mother, "who brought it up as a Girl in Apparel and at School, and to handle the Needle, till it was 12 Years old, when he turn'd Man and went to sea." Additionally, Boon appeared in court and testified to being a hermaphrodite convincingly: "She was also produc'd in Court, and own'd her being a Hermaphrodite, and having been shown; and it appearing by her own Confession as well as other Evidences that the Woman was more predominant in her than the Man." ${ }^{24}$ As a result of the evidence presented, the jury acquitted Jones of bigamy and released her from prison. ${ }^{25}$

This decision - that Boon was more woman than man-was the easiest way to restore social order: in eighteenth-century England, both bigamy and sodomy were severe crimes that could be punished by hanging, but same-sex intimacy between women was not criminalized as was such intimacy between men (Binhammer 2010, 2; Olsen 2017, 29-33). Additionally, juries in bigamy cases were reluctant to send bigamists to be hanged and tended to acquit defendants when some supporting evidence was presented (Capp 2009, 553). These circumstances might explain why Jones preferred to admit that she had engaged in a void marriage with an individual who was possibly a woman - it would give the jury a way to avoid punishing her for bigamy. And if Boon wanted to protect Jones, presenting as a feminine hermaphrodite was likely the best strategy for doing so. Nevertheless, when Boon died in 1768 (Gentleman's Magazine $1768,246)$, the case appeared in several reprints with an editor comment that affirmed the underlying fear of harming male privileges, such as marrying a different man's wife: "We can only express our astonishment that an hermaphrodite should think of such a glaring absurdity as the taking of a wife!" (Tyburn Chronicle 1768, 329; Jackson 1794, 248).

Although no evidence regarding Boon's anatomy was brought to court, hermaphroditic bodies in general were treated as a central site for community validation of sex, often in ways that undermined the individual's wishes and autonomy. In the eighteenth-century world surrounding the Atlantic, the bodies of people of lower classes were often stripped and inspected. Unlike aristocrats who rarely exposed their skin, the bodies of the politically weak were more visible and scrutinized: the poor, runaway slaves, prisoners, army deserters, patients, or sex/gender transgressors were routinely inspected, described, and publicized (Morgan and Rushton 2005). Hermaphrodites'

23. Case of Katherine Jones, 1719, Proceedings of the Old Bailey, 1674-1913, https://www. oldbaileyonline.org/.

24. Katherine Jones.

25. The mention of a jury was made only in the reproduction and not the original court record. See (Tyburn Chronicle 1768, 329). There is no indication that the court was aware of medical evidence and intentionally excluded it. The only evidence suggesting the lack of medical testimony in this case is its absence from the transcript. 
sex was also a "subject for collective decision making," and their bodies could be readily accessed by community members for observation and evaluation (M. Norton 1997, 55). Hall's body was frequently examined by the townspeople, and Boon's was examined first by her mistress and then by ticket buyers and physicians. There is no evidence that Boon agreed to participate in such exhibitions; according to Douglas's report, Boon stated that she was sent to Smithfield fair by her mistress. Ruth Gilbert (2002, 13638) argues that such public spectacles of hermaphrodites profited from the "colonial excitement" of seeing and knowing the body and further from the erotic nature attached to hermaphroditism. In these spectacles, scientists pried naked hermaphroditic bodies, determined to prove their sex, and made them into public scientific experiments (149). According to Guerrini (2016, 30), the "monstrous" or subhuman signification of hermaphrodites allowed physicians to subject their bodies to invasive and painful examinations and to produce detailed illustrations that were otherwise considered indecent at the time. As we will continue to see, people's autonomy over their naked bodies was expropriated once their sex became a matter of doubt.

As mentioned earlier, this preference for having juries and lay witnesses, rather than medical professionals, decide hermaphrodites' sex is unique to common law and contrasts with the then existing practices in civil law, which was practiced in other countries on the continent. For example, Daston and Park (1985, 6; 1995, 425), historians of science who examined the history of hermaphrodite regulation, explain that in France, as early as the sixteenth century, medical commissions were appointed to help adjudicate defamation disputes in which one side called the other a hermaphrodite. They report that French magistrates referred alleged hermaphrodites to designated medical commissions consisting of surgeons, physicians, apothecaries, and midwives, and the magistrates deferred to these commissions' judgments in every known case. ${ }^{26}$ Scholarly literature indicates that such judicial reliance on medical classifications of hermaphrodites in continental countries persisted throughout the nineteenth century. ${ }^{27}$ England, however, showed no such reliance on medical testimony in the case of hermaphrodites until late eighteenth century.

The difference between English and French courts can be explained by differences between the common law's and continental law's doctrines of evidence. The common law's commonsense philosophy placed its faith in "the good sense of the laymen" so juries, rather than experts, were granted the authority to determine judicial facts (Boorstin 1996, 111). Medical experts had been invited to testify in common law courts since the earliest days of common law, and, by the early modern period, such testimonies were in frequent use in England (Darr 2014). However, during most of the eighteenth century, expert knowledge was not granted special status in the doctrine of

26. Such medical commissions established their examinations based on three primary characteristics identified by the Swiss physician Bauhin: personality, secondary sex traits, and, most importantly, genitals. See Daston and Park 1985, 2-3.

27. Geertje Mak (2013) describes the reliance of civil courts on medical examinations of hermaphrodites. Although the book details only nineteenth-century cases, according to the author, the study was conducted using more than three hundred medical histories from mostly France and Germany published between the end of the eighteenth century and the early twentieth century). See also Poppesco 1875 (describing how new knowledge in anatomy and embryology transformed the operation of medico-legal experts who testified in courts and tribunals on the sex of hermaphrodites). 
evidence law. Indeed, before the modernization of evidence law doctrine, there was no meaningful difference drawn between the testimony of experts and that of lay witnesses in common law courts. ${ }^{28}$ As Tal Golan $(2004,19)$ notes, experts ordinarily appeared either as regular witnesses or as specialized juries (the most well known of which was the all-female jury of matrons, usually summoned to make factual determinations in cases of sexual assault, pregnancy, and childbirth). It seems that, while the use of experts was becoming more prevalent in England in some contexts (such as homicide trials) during the eighteenth century, the question of hermaphrodites was still considered non-scientific and was therefore under the purview of regular juries, with the addition of the specialized authority of females over the sexed body during community investigations, as we saw in Hall's case with the group of married women.

The nearly absolute dependence of common law on the knowledge of lay witnesses changed in the late eighteenth century, when Lord Mansfield's decision in Folkes $v$. Chadd legitimized and endorsed the use of expert testimony to prove "matters of science." 29 In the decades that followed, expert testimony was granted special status and privilege, and this status began receiving doctrinal recognition. The fourth edition of Geoffrey Gilbert's (1795) The Law of Evidence from 1795 was the first evidence treatise to identify and define expert testimony as a special practice. ${ }^{30}$ Following the habit of French lawyers, the treatise named this practice "proof by expert" and described its reliability. The authority of experts to provide opinions in their testimonies was further formalized in modern evidence law theory (Golan 2004, 53). This change in the judicial status of experts and in the relevance and credibility of their opinions led to the growth of medico-legal studies, and fostered the development of English medico-legal forensic science, almost two centuries after this development in continental Europe. ${ }^{31}$

According to Catherine Crawford $(1994,89)$, differences between the legal systems in England and those in continental countries were "crucial factor(s)" in explaining why medico-legal science lagged behind in England. First, unlike in England, continental systems provided medical experts with a formal status that made the practice of medico-legal investigations lucrative, exclusive, and desirable by physicians. English physicians, on the other hand, were reluctant to appear in court for lack of proper compensation and appreciation (91-94). Second, the law of proof developed differently. Moving from the Middle Ages' proof by ordeal or battle, English common law used jury trial designated to reach "lay consensus" on disputed facts. In continental Europe, however, proof by ordeal or combat was replaced with judicial inquisition into the matter, without the involvement of juries (95-96). This difference led to the development of authoritative doctrine to help judges sort out evidence and testimonies in specific circumstances based in medical expertise and forming a massive body of medico-legal literature. The use of professional judges as fact triers in continental countries made it easier to integrate technical evidence in trials than in common law courts

28. Whereas according to contemporary evidence doctrine, only expert witnesses are allowed to testify to their opinion, during the early modern period, lay witnesses also often stated their opinion and did not limit themselves to the facts of the case. Gallanis 1999, 515.

29. Folkes v. Chadd, [1782] 99 Eng. Rep. 589 ("[i]n matters of science, the reasoning of men of science can only be answered by men of science").

30. See Golan 2004, 53, quoting G. Gilbert 1795, 301.

31. Crawford 1994. 
(97-101). Throughout most of the eighteenth century, English judges and juries did not use medico-legal investigations when determining the sex of hermaphrodites. Instead, judicial fact finders relied on their common sense and intuitions.

While both the juries, who relied on their commonsense judgment, and Douglas, who practiced a scientific examination, arrived at the same conclusion-that Boon was a woman, they did so on different grounds. Douglas viewed, touched, and probed Boon's body, whereas the juries listened to testimonies and observed Boon and the other witnesses. Douglas compared her female genitals (labia, clitoris, and vagina) to the size and shape of male genitals (penis, scrotum, testicles, and urethra) and arrived at the conclusion that she was a "real woman," whereas the jury was exposed to Boon's life narrative, her upbringing, her education and training, and the fact that she switched to male presentation at the age of twelve and was presented as a hermaphrodite. It seems that because common law courts relied on evidence presented by lay witnesses, judicial classifications did not focus on bodily sex but, instead, relied heavily on the social or lived experience of sex. I argue that common law's philosophy of valorizing commonsense knowledge and the use of the jury system to determine sex enabled rich concepts of sex to persist despite the rising authority of medical and scientific knowledge in extralegal fora.

More importantly, however, the juries and Douglas ruled based on opposing theories of sex. Whereas the juries classified Boon according to the common law framework established on the Hippocratic/Galenic dominancy model of sex and announced that Boon was "more female than male," Douglas introduced a new concept of sex-the idea of "true" or "real" sex, which related to the Aristotelian concept of sex that placed males and females as opposites. ${ }^{32}$ As we will see, the rising status of experts in common law had far-reaching effects on the identity of sex classifiers, the evidence that would be examined in court to determine sex, and the very concept of sex itself.

\section{Cavalier d'Eon (1771-78): Erosion of Lay Knowledge}

In addition to the reliance on lay witnesses, Hall's case exhibited the informal authority of women acting as lay experts, an authority likely drawn from the all-female special jury. The jury of matrons was an English legal mechanism designed to provide the court with authoritative opinions on the female body in relevant legal contexts, such as rape, pregnancy, virginity, impotency, inheritance, and other instances that require examination of the female body (Oldham 2006, 80-104), especially from the sixteenth century until early in the eighteenth century (Forbes 1988, 22-33; S. Butler 2019). Although Hall's case demonstrates a cultural reliance on the judgment of such knowledgeable woman, the three trials concerning the sex of Cavalier d'Eon toward the end of the century-between 1771 and 1778-represent a diminishment in the cultural authority of female inspections and the classification of hermaphroditic bodies. They also show the judicial aspiration to separate the court from salacious collective investigations into a person's sex and to situate the court as a virtuous and civilized forum.

32. Foucault (1980) dates this transition in the eighteenth century in his introduction. 
Although d'Eon's character and life have been a fruitful source of study for scholars in the fields of early modern history and the history of sex, gender, and sexuality, here we will analyze d'Eon's trial records and examine them against the backdrop of scientific revolution and growing medical expertise. Doing so exemplifies a major shift in the judicial interrogation of sex that occurred at the turn of the eighteenth century-a shift in which learned minds moved from relying on common sense to relying on science in the classification of sex. The jury of matrons' mechanism that was in use at the time occupied a middle ground between these two approaches. These matrons were supposed to examine the female body, but they may have been inspecting male bodies as well, as had been the case for centuries. In medieval England, for example, "wise women" assisted ecclesial courts in cases where a woman requested annulment of her marriage due to her husband's impotency. According to Jacqueline Murray (1990, 240-42), these courts appointed a group of "honest women" to confirm such impotency, and, in such cases, the wise woman would not only examine and touch the husband's genitals but would also sometimes attempt to arouse him sexually (242). Although it is not clear to what extent these kinds of ecclesiastical and canon law procedures for engaging matrons correlated with common law court procedures (Oldham 2006, 83), the common law court's need to determine a person's sex may have triggered its engagement of matrons to conduct similar inspections in an informal manner.

One humorous instance of such an inspection occurred as part of the incredible case of Chevalier d'Eon. Born in 1728 in a small town in Burgundy, d'Eon studied in Paris; he then became involved in French diplomacy and espionage in England, where he was part of a web of agents employed by the French Foreign Ministry called “The King's Secret" (Conlin 2010, 46). D'Eon's physique was known to be androgynous. Although it is not clear whether he had a habit of occasional cross-dressing in his youth, ${ }^{33}$ rumors that d'Eon was a woman started circulating in London starting in the 1770s. He had already become a public figure by that time, so his sex became a popular topic for bets on London's stock market (50). As with Hall and Boon before him, the question of d'Eon's sex was a public one, well suited for conjecture and independent examination. Satiric documentation of what looks to be a mock trial to determine d'Eon's sex was published in The Town and Country Magazine (1769), an eighteenth-century journal that shared the affairs of London's upper class and "veiled 'scandal' tales, parodic 'oddities,' and satirical narratives" (Pitcher 1983, 44). The featured trial was conducted by a jury of matrons, summoned to determine d'Eon's sex conclusively: "The chevalier resolving to do himself justice, and prove his virility, had solicited several ladies of the first fashion, well known in the republic of gallantry, and completely qualified for the office, to form a jury of matrons" (Town and Country Magazine 1769, 249). The magazine published the alleged transcript of two sessions, with a parodic illustration and some ridicule of the matrons who attempted to determine d'Eon's sex based on their past infidelities and experience with men (Burrows et al. 2010, 117).

33. Writings on d'Eon's life usually address him as a man or as some type of intermediate sex (such as a hermaphrodite, "neuter," cross-dresser, or transvestite) (Burrows et al. 2010, 2-3). For references to him as male, see A Short Sketch 1810, 23; Wraxall 1861, 150. For references to d'Eon as an eighteenth-century transvestite/cross dresser/hermaphrodite, see Brogan 2010; R. Norton 2005. 


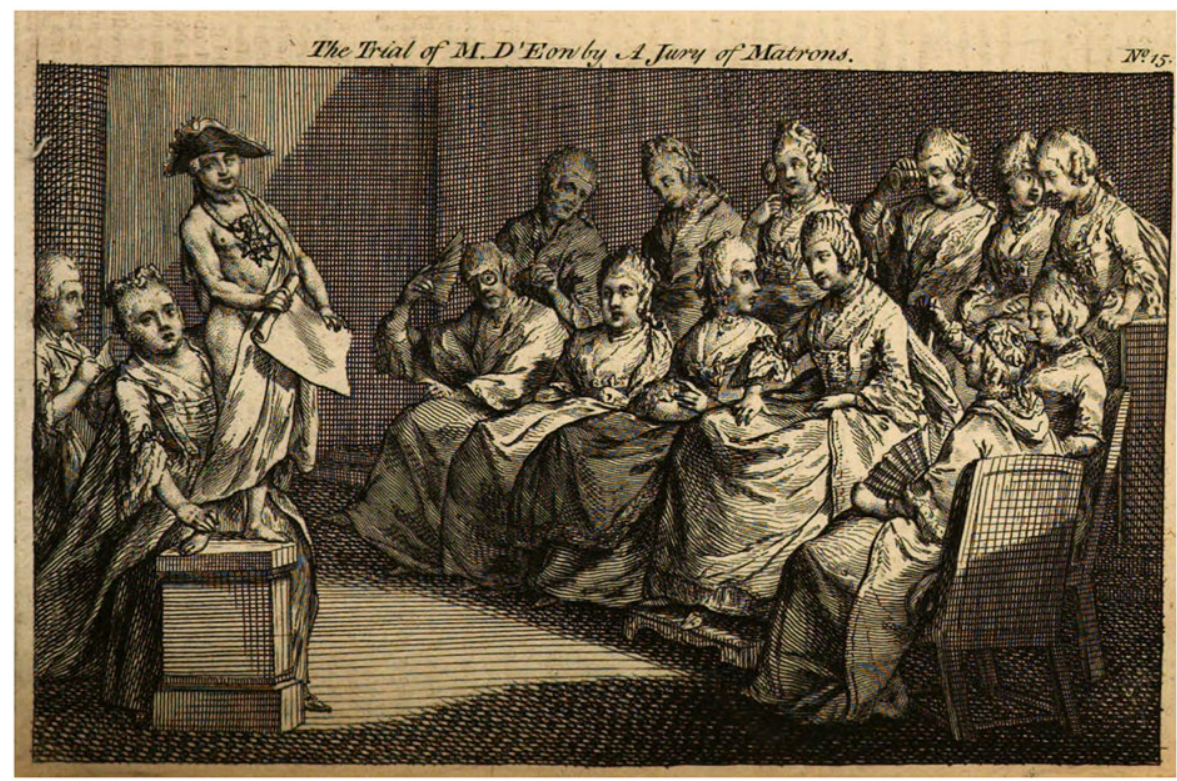

Figure 2.

The trial of Chevalier d'Eon by a jury of matrons, in The Town and Country Magazine, vol. 3, 1771. Credit: Public domain, Google digitized; courtesy of HathiTrust, https://babel.hathitrust.org/cgi/pt?id $=$ hvd.hw28e0\&view $=1$ up\&seq $=$ $276 \& q 1=\mathrm{d} \% 27$ Eon.

The publication of this mock trial was part of an established genre in eighteenthcentury England: the publication of erotic trials. Emerging as a distinct branch of crime literature, newspapers and publishers printed detailed trials of divorce, adultery, impotency, and sexual perversions to attract buyers. These trials became "a popular form of soft-core pornography" (Kinservik 2008, 10), and they were even more interesting when they involved high-ranking people and aristocrats. According to Peter Wagner (1982), medical reports in divorce trials had commercial value as they played "to the reader's prurient interests" and were therefore placed in the title page. Sometimes they featured reports of matrons appointed by the court (Town and Country Magazine 1769, 225). The title page in d'Eon's case promised "[a] humorous representation of a Jury of Matrons deliberating on the sex of the Chavalier D'E$\mathrm{n}$," indicating both a cultural tradition of matrons determining sex and also an erosion in their status and that of their determinations in the late eighteenth century. The fact that d'Eon was a public figure made his mock trial suitable for publication. According to Wagner, pornographic trials were also an opportunity to embarrass French aristocrats. This mock trial implied that a known French spy and diplomat might be an impotent man or woman. Indeed, the accompanying illustration depicts d'Eon as proportionally smaller than the English matrons and as wearing a French symbol-the order of St. Louis necklace-around his neck (see Figure 2). ${ }^{34}$

34. "The Trial of M. d'Eon by a Jury of Matrons," Digital Transgender Archive, https://www. digitaltransgenderarchive.net/files/9z9030116. 
As in the later reprints of Boon's case, the worry about blurring male-female boundaries was introduced here again, raising the specter of the formation of illegal marriages and the spread of adultery and divorce. The opening remarks by the chairwoman Lady Harrington stressed these fears, saying that this examination was important to the next generation because "if under the appearance of a male figure, any of our daughters should be so far imposed upon us to wed a woman, or even an hermaphrodite, what a disappointment must it not only be to them but our families, which may by that means become extinct!" (Town and Country Magazine 1769, 249). The report continued to describe the examination. Given the characterization of these trials as pornographic, it seems likely that the report of this one would include a thorough description of d'Eon's private parts. However, although the illustration depicts a visual examination of d'Eon's body using magnifying instruments (such as glasses and a telescope), the transcript mentions nothing of d'Eon's body form or genitals. Instead, it reveals a parodic rationalization process; perhaps inspired by the historical contexts in which a wise woman aimed to arouse a husband's suspected impotence (Murray 1990, 246), d'Eon's matrons based their judgments on their success (or lack of success) at seducing d'Eon: "I threw out every possible lure to induce him to make overtures to me, and almost solicited him to my bed, I never could get a tender thing from him" (Town and Country Magazine 1769, 249-50). On his writing skills, they declared: "I think he has so much sense to be a woman's man; for all my lovers have been fools, and could never write a little better than myself." The first meeting adjourned with the conclusion that d'Eon's sex was "Doubtful" and scheduled to meet again soon "to determine finally whether the chevalier should remain of the Epicene gender"- that is, of indeterminant sex. ${ }^{35}$

The second meeting opened with a resolution that d'Eon was female (Town and Country Magazine 1769, 305). D'Eon allegedly appealed the decision by arguing that such a conclusion would create great damage to the French court and nation (for having appointed a woman as a diplomat) and would jeopardize the peace treaty between England and France (306). The matrons' further discussion revolved around their attitudes toward the peace treaty with France. At this point, d'Eon's sex classification reflected their political preferences and personal beliefs. They did not change their ruling that d'Eon was a female and reported that d'Eon thanked them for "the impartial sentence, and just determination they had made in her favour." Although the matrons had promised to remove doubt from d'Eon's sex through an impartial sentence, the public was not convinced. Despite the publication of the matrons' decision, d'Eon's sex remained unresolved in the stock market, and bets regarding d'Eon's sex generated legal disputes. The mock trial transcript ridiculed the jury of matrons and portrayed them as frivolous ladies with extensive sexual experience who used their sexual seduction capacity whimsically and not as a reasoned method for determining sex. Six years after the publication of his mock trial by the jury of matrons, d'Eon's sex became the subject of lawsuits in a real court of law.

35. "Epicene gender" has been in use to describe people or animals having characteristics of both sexes, or of neither, with indeterminate sex, androgynous, or hermaphrodite since the seventeenth century. See Oxford English Dictionary Online, n.d.a. 
The cases, which were adjudicated by Chief Justice Lord Mansfield in the Court of King's Bench in 1777 and 1778, stand in stark contrast to the depiction of d'Eon's mock trial-they reveal how changing social norms of modesty and honorability shaped the process of fact making in the context of doubtful sex in common law. In the first case, Hayes v. Jacques, Mr. Hayes, a surgeon, paid Mr. Jacques, a broker, a sum of one hundred guineas in hopes of receiving seven hundred guineas if Hayes were able to evince that d'Eon was a woman (Ashton 1898, 159-61). ${ }^{36}$ To offer proof, Hayes invited two witnesses who knew and had interacted with d'Eon. Both witnesses attested that d'Eon was a woman, based on their view of d'Eon's body and the accompanying interaction on that occasion. The first, a surgeon named Mr. Goux, testified that "to his certain knowledge, the person called the Chevalier d'Eon was a woman" (159). In his cross-examination, he further explained that he examined d'Eon (at d'Eon's request) regarding a disorder, which led to the discovery of d'Eon's being a woman. The second witness, Mr. de Morande, testified that d'Eon had disclosed his female sex, wardrobe, and body to him on one occasion when d'Eon had invited de Morande to his house $(160) \cdot{ }^{37} \mathrm{He}$ further testified that, on one morning, the Chevalier had invited the witness to approach "her bed, and then permitted him to have manual proof of her being, in very truth, a woman" (160). As suggested earlier, both witnesses' testimonies-including that of the surgeon-hinged not on abstract scientific theories regarding doubtful sex but, rather, on the direct observation of d'Eon's body and interaction with him. A newspaper reporting on the case described the two witnesses as "physical gentlemen" to possibly signal their medical expertise (Morning Chronicle and London Advertiser 1777).

Despite this move toward a more scientific/medical form of reasoning, however, Lord Mansfield was appalled by the inquisition and "expressed his abhorrence of the whole transaction, and the more so, for their bringing it into a Court of Justice" and wished the dispute "might have better settled elsewhere" (Ashton 1898, 161). Nevertheless, Mansfield acknowledged that the law did not prohibit bets on this topic and advised the jury to find a verdict for the plaintiff Hayes, which it did, thus deciding winners and losers in all other outstanding bets on the topic (162). ${ }^{38}$

A chance for Mansfield to repair the King's Bench respectability arrived a year later, on January 31,1778, when the question of d'Eon's sex was raised again in $D a$ Costa v. Jones..$^{39}$ In this case, the defendant's counsel laid out two arguments appealing the jury's earlier decision. The first was that the decision should not be enforced because it required the introduction of "indecent evidence" to the court and the second (suggested by Mansfield himself) was that "it materially affects the interests of a third person." ${ }^{40}$ Lord Mansfield accepted the latter argument, affirming d'Eon's interest in the

36. Hayes v. Jacques was unreported, but described in newspapers and magazines (Swain 2015, 237).

37. See also Morning Chronicle and London Advertiser 1777), which describes Morande as an interpreter to a different French witness who does not speak English.

38. Some evidence implies that there may have been another witness, perhaps a servant or an employee. In d'Eon's reaction to the verdict as it was published in public papers on August 10, 1777, he said: "It will then be the proper time and place to offer all my reasons against the three witnesses who gave evidence on my sex" (see Short Sketch 1810, 21).

39. Da Costa v. Jones, [1778] 98 Eng. Rep. 729, 729.

40. Da Costa, 731. 
privacy of his sex. Mansfield also regretted that he had previously allowed confidential friends, acquaintances, and professionals to offer testimony on the issue and wished that they had refused to testify. ${ }^{41}$ Although this may seem like a revolutionary ruling that signaled a humanization of hermaphrodites and viewed them as subjects of privacy, it was not so. Mansfield concluded that a person's sex could be a legitimate subject for judicial interrogation depending on context and that, in contexts such as the case of a hermaphrodite heir, such an interrogation would be appropriate. In other instances, however, such as to rule on a bet, it would not be so. ${ }^{42}$ In other words, he declared that judicial examination of a person's sex would be perfectly fine when the hermaphrodite person was party to the legal dispute and the fact of their sex had legally enforceable consequences.

Reading Mansfield's decision in d'Eon's case against the backdrop of the mock trial by the jury of matrons reveals a tension between competing methods of proof, both contained within the common law tradition. Mansfield's decisions in these cases seem to have been written to distance the King's Bench from the indecency and primitiveness associated with the jury of matrons' authority and the obscenity of pornographic trials. According to James Oldham $(2006,113)$, the use of the jury of matrons apparatus had already decreased dramatically after 1720 , partly due to growing medical and scientific authority of physicians. This change may explain why, by the end of the century (1771), the idea of sex determination by matrons had migrated to the realms of satire and ridicule and why Lord Mansfield wanted to distance the King's Bench from this tradition. Nevertheless, the court still relied on community witnesses rather than medical experts. The doctrinal shift away from such witnesses and toward experts and science would follow Folkes $v$. Chadd some years later, and this shift would reduce common law's traditional reliance on lay witnesses in such questions.

Hints to this shift appeared when d'Eon died in 1810, and a group of doctors, anatomists, surgeons, and other respectable men conducted a "complete inspection and dissection of the sexual parts" (Short Sketch 1810, 5). The report included a comprehensive description of his body, addressing in detail his face, body hair, arms, hands, fingers, and more, suggesting that they were feminine and "enabled him with more ease to carry on such a deception." However, the group "decidedly ascertained, that the conformations of the organs was that of a male; and that all doubts, as to the identity of the person, might be removed," likely due to their examination and dissection of his sexual parts, which are not detailed in the report. These findings made their way into later reprints of the Hayes v. Jacques case, which concluded with this statement: "When d'Eon died, in London, in 1810, it was proved, without a shadow of a doubt, that he was a man" (Ashton 1898, 162). As we will see in future cases as well, the transition from community and lay expert knowledge, such as that of the jury of matrons, to medical knowledge and expertise in d'Eon's case indicates a desire for "doubt-free" proof and for evidence about sex that can be described as infallible.

In the era preceding scientific soundness, community investigations and their operation in court in the cases of Hall, Boon, and d'Eon demonstrate the way in which commonsense understandings animated the dominancy rule. The unstable and 
contingent nature of communal knowledge about sex meant that the legal fact of sex, which relied on that knowledge, could contain some doubt. That was acceptable in the legal system, where factual determinations were secondary to the primary objective of solving disputes; as a result, the fact of sex was determined instrumentally. Said another way, the dominancy of sex in legal settings was contextual and provisional and could potentially change. To be clear, medical knowledge of hermaphrodites at the time was also contingent and inconsistent; however, unlike judicial commonsense inquiry, the scientific inquiry sought to arrive at the correct answer and eliminate doubt as much as possible.

While the legal determination of sex remained instrumental throughout history, in the late eighteenth century, when sex became construed in the terms of a scientific fact, doubt was set to disappear from the legal fact of sex and from its legal determination. The idea of eliminating doubt using superior evidence interpreted by learned men was appealing to the common law judges. The next case demonstrates a part of this transition in which a late eighteenth-century judge surrendered easily to what he believed was superior knowledge and to a view of himself as an enlightened fact maker.

\section{Betty John (1787): Judges as Enlightened Fact Makers}

In addition to relying on communal testimonies, judges projected their own beliefs and understandings of sex into the courtroom. But in what way was judicial knowledge different from communal knowledge, if at all? This section will illustrate a judicial aspiration to facilitate a learned and "enlightened" procedure of proof to determine the sex of so-called hermaphrodites, as distinct from the procedures conducted elsewhere (for example, public fairs, the stock market, a mock trial). In d'Eon's cases, for example, Lord Mansfield wanted to separate the court from popular investigations of sex. Over time, justices further diminished the authority of lay understandings of sex and acceded to medical proof. One way in which justices utilized their specialized status was through the administration of evidence. Sheila Jasanoff (2018, 15-17) suggests understanding judges as "epistemological gatekeepers" who choose between types of authority without formal limitations. Given this understanding and the fact that modern evidence procedures were not formalized and were not consistently practiced in courts before the mid-eighteenth century, justices of the time enjoyed great procedural discretion when ruling on sex classifications. ${ }^{43}$

When judges operate as epistemic gatekeepers, I argue, they are required to negotiate between their commitment to local common sense and their duty to function as skilled triers of fact. As Jasanoff $(2018,17)$ argues, discretionary judicial acts are not mere subjective arbitrary actions but, rather, "amplifiers of common sense," as they seek to follow a reasoning that is "rooted in engrained collective beliefs." On the other hand, at least in theory, fact-finder justices operate under the mode of "trained observers" who possess the expertise to evaluate and administer evidence in an educated and

43. It has already been recorded that even by the mid-eighteenth century, common law justices used much of their discretion in the administration of evidence law, in the application of the hearsay rule, or in instructing jurors as to the correct result. See Langbein 1996, 1190; Gallanis 1999, 512-13. 
accustomed manner (Riddell 1918, 1003). Their administration and evaluation of evidence within the sea of informality is designated to reflect a higher standard of judgment and reasoning - that which is held by a learned professional judge and not by "tailors and shoe-makers" (1004). For common law justices, epistemic gatekeeping is conducted within these conflicting commitments: to higher reason, on the one hand, and to common sense, on the other hand.

In the context of doubtful sex, the question of whether to turn to experts to determine sex very much hinged on whether justices viewed the matter as scientific and as a question of their understanding of sex. It seems that for most of the eighteenth century common law justices figured that sex determination was in the purview of common sense, but toward end of the century, they began to view sex determination as a scientific matter that required external expertise. The trial of Betty John shows the efforts made by an English court of requests to make factual determinations that speak to commonsense logic but, at the same time, to assume judicial expertise that echoes scientific ideas about hermaphrodites. ${ }^{44}$ As described earlier, the surgeon James Douglas (who examined Boon in 1715) had already argued that true hermaphrodites do not exist and that those perceived to be hermaphrodites are actually "deformed women" (Guerrini 2016, 31). ${ }^{45}$ Some decades later, James Parsons (1741), a physician who was admitted as a fellow of the Royal Society as well as a former student of Douglas, published A Mechanical and Critical Enquiry Into The Nature of Hermaphrodites. The text was written following the arrival in London of "[t]he Angolan," a celebrated hermaphrodite who was exhibited in different theaters and cafes (Parsons 1741, 1751, 142). Parsons's (1741, vi-x) primary aim was to convince both popular opinion and learned individuals that hermaphrodites do not exist among humans and that believing that they do is a superstition or vulgar error that needs to be abandoned.

Such denial of the existence of hermaphrodites was intertwined with the gradual acceptance of the Aristotelian model of sex, which viewed males and females as opposite ends of a distinct binary and rejected the dominancy model embedded in the old law (da Costa 2004, 137). Eighteenth-century English dictionaries already expressed this view in their definitions of "Hermaphrodite," ${ }^{46}$ and toward the mid-nineteenth century, admitting that hermaphroditism existed was seen as a token of ignorance and boorishness in medical circles (Dreger 1998, 139; Reis 2009, 8). ${ }^{47}$ The association of this belief with vulgar commonality also appears in the case of Betty John, held at the Birmingham Court of Requests in England. The report begins by describing a potential plaintiff who wished to sue a potential defendant for failing to pay a debt (without further details); however, the plaintiff was not sure of the defendant's sex because the

44. Case of Betty John, 1787, Court of Requests, Birmingham, 419.

45. Douglas's 1715 manuscript was not published in print but only delivered to the society. His illustrations were published in 1722. See Cheselden 1722, 319-22.

46. See, for example, Chambers 1741; Society of Gentlemen 1754, 1612 ("[i]t is now generally allowed, that there is no such thing as a true hermaphrodite; most, if not all those who pass for such, being mere women, whose clitoris is grown to an enormous size, and the labia pudendi become unusually tumid"); Encyclopaedia Britannica 1771, 784.

47. Alice Dreger (1998) explains that by the late nineteenth century, hermaphrodites were "killed off" by medical and scientific authorities, who cooperated in changing the criteria of true hermaphroditism to the point that it was impossible to comply with. 
defendant had been known in public in both male and female presentations. Following unsuccessful inquiries into the matter, the plaintiff filled out the summons with two names_Elizabeth Alias and John Haywood—and added: "Let the sex be what it would" (Hutton 1787, 425). Although the plaintiff's name and the exact date and year of the case are not mentioned in the report, it was published in a thick volume from 1787 and written by William Hutton, who served as a commissioner and president in Birmingham's Court of Requests sometime after 1769 (Elrington 2004).

As will be made clear, Hutton's (1787, ix) report of the case is not a mere presentation of the facts and legal outcome, but it can also be read as a firsthand monologue that describes the dilemmas and contemplations of one judicial fact finder in a case of doubtful sex in late eighteenth-century England. ${ }^{48}$ The report echoed the historical association of hermaphroditism with sub-humanity: "The animal appeared in court in a female habit, was rather elegant, of a moderate size, tolerably handsome, about thirty-two, had a firm countenance, and manly step, no beard, eyes susceptible of love, a voice tending to the masculine, with manners engaging, and was rather sensible" (426). The name attributed to her was Betty John, but Hutton did not seem convinced she was indeed a female: "As it attended the court in female dress, I shall take the liberty of treating it with a feminine epithet" (426). This representation of John by Hutton reflects the turning point described by Elizabeth Reis (2009, 22-23), who argued that starting in the late eighteenth century, the anxiety that dominated the interpretation of hermaphroditic bodies by doctors had changed. The old fear of godly wrath as manifested in monsters was gradually replaced by fears related to crossing racial and sexual boundaries. Accordingly, hermaphrodites were not perceived so much as monsters but more as deceivers or frauds.

As in the earlier cases, the question of John's sex became crucial to the outcome of the legal proceeding - if she were a married female, as suggested by the presence of her alleged husband in the courtroom, the disputed debt might have been voided under the rule barring wives from forming contracts (Hutton 1787, 426). ${ }^{49}$ Because her sex and marital status were fundamental to the result of the procedure, the court was presented with evidence regarding John's sex and the validity of her marriage to the man. ${ }^{50}$ In one version of the report, it is implied that a marriage certificate was "passed from hand to hand for inspection" but was not accepted, as it looked like it had been scribbled by a "school-boy." This mention raises the possibility that a jury was appointed, but considering that this is a simple procedure in the court of requests, it is likely that the hands and eyes inspecting the note belonged to the people in the courtroom. ${ }^{51}$

The report offered a candid consideration and evaluation of the evidence presented in this case, which demonstrates that Hutton was attempting to follow the ideal of a learned and civilized judge. Hutton $(1787,426)$ mentions that "the common opinion of the ignorant, who knew her, was, that she was an hermaphrodite. Partaking of

48. From William Hutton's (1787) report of the case, it seems that Hutton served on this case with more commissioners.

49. According to the legal doctrine of coverture in English law, the rights of a married woman were subsumed by those of her husband, and she could not contract or own property. See Stretton and Kesselring 2013, 29-36.

50. A marriage certificate presented was rejected by the court (Hutton 1787, 429).

51. "Court of Requests," n.d. 
both sexes." He further noted that the belief in the existence of hermaphrodites belonged to an era "marked with credulity" in which "every ear was open to wonder." As noted, by the mid-eighteenth century, the notion that hermaphrodites did not exist and were most likely females or males had already started taking root in the learned texts of anatomists and surgeons. The idea that hermaphrodites did exist became associated with a lack of sufficient knowledge about the body and with an old, primitive world. As a result, Hutton evaluated evidence brought to him according to these higher standards of validation, and he concluded that John was actually a man in disguise-a husband and not a wife:

It appeared, from undoubted evidence, that, while she dressed like a man, she was suspected to be a woman; but in both dresses was strongly suspected to be a man ... while the defendant carried a male dress, she spent her evenings at the public house with her male companions, and could, like them, swear with a tolerable grace, get drunk, smoke tobacco, kiss the girls, and now and then kick a bully. Though she pleaded being a wife, she had really been a husband, for she courted a young woman, married her, and they lived together in wedlock till the young woman died, which was some years after and without issue. She afterwards, like people of higher rank, kept a mistress, and ran away with her. Forcible evidences like these were sufficient to convince the wisest head upon this bench, or any other, that a man in disguise stood before them. (Hutton 1787, 426-27; emphasis added)

Following this presentation of "forcible evidence" pertaining to John's romantic history and mastery of masculine behaviors, the court was persuaded that John was not a woman and not a wife but, rather, a man and, therefore, liable for the debt: "Her wife living peacefully with her all her days, without one complaint of the breach of the marriage covenant, evinced there was no defect.... Her being well versed in the art of kicking, further proved she was a man" (Hutton 1787, 428). John's sexuality and ability to pass as a man were threatening to the status quo. Here, as in Boon's case, a finding that John was a woman would have had atrocious implications for the separate spheres' ideology — after all, if a woman could so successfully occupy a male-dominated sphere, what justified the separation in the first place? The socio-political separation between men and women was established based on clear and determinant differences between males and females. Accordingly, deciding that John was a woman would jeopardize the validity of this premise, so this conclusion was not one the judge was willing to draw easily.

However, a major turning point arose after John failed to pay her debt and was sent to prison. Then, Hutton $(1787,429$, emphasis added) reports: "It appeared from incontestable proof, that she was a real woman, and a real wife." Hutton's report implies that such evidence was probably gathered through physical examination upon John's arrival to prison: "[S]he had nothing of the man about her higher than the feet." According to the report, it was not possible to change the verdict in her favor at this point, and, eventually, John "cancelled the debt, by a confinement of forty days" (429). The fact that Hutton surrendered to supposedly physical evidence implies that he grew to believe that a superior means of proof was available outside of court and foreshadows what came 
next: judicial submission to professional classifiers who examine the body. His use of phrases such as "real women" and "real husband" as well as his decision to introduce the case under the heading "error in judgment" suggests that Hutton was impressively skeptical regarding his own capacity to make a "correct" classification (425).

Considering that Hutton identified John's original classification as male almost completely based on behavioral factors such as her "masculine" traits and actions, while referring to her anatomy only implicitly by mentioning her satisfying marriage to a woman, as well as his later change of mind after discovering presumably physical evidence, also indicates the growing authority of the physical body over social indications for determining legal sex. The case of Betty John as reported by Hutton offers insight into one judge's state of mind when administering evidence regarding a person's sex. Hutton asked to distinguish judicial reasoning from the ignorant opinion found on the streets-that John was a hermaphrodite-and presented an evaluation of evidence that he believed would make sense to both the "wisest heads" and to "any other" person. Then, he was forced to confront the deficits in his own knowledge and reasoning. Although his approach to judicial sex is instrumental (that is, he treated the definition of sex as a necessary step to apply the law correctly and solve the dispute), he used new terminology with respect to sex. He used language that identified it as a condition that has true and false qualities and that can be evaluated and classified outside the court by using better evidence and methods than those available to judges.

\section{THE DEVELOPMENT OF THE SEX/GENDER DIVISION IN EIGHTEENTH-CENTURY COMMON LAW}

So far, this article has dealt with how early modern common law differentiated between the sexes. We have learned that judicial classifications of people with doubtful sex often hinged on social, economic, legal, sexual, and political differences between males and females at the time. This is exemplified in the argument made by Joan Scott $(1988,2)$ in Gender and the Politics of History that "nothing about the body, including women's reproductive organs, determines univocally how social divisions will be shaped." Instead, Scott argued, the social organization between males and females is a result of discourses about sex differences. Accordingly, it is crucial that we ask how social hierarchies were constructed and that we critically examine how they are perpetuated in the knowledge and discourse on sex differences (2-4). Further along this path paved by Scott, it seems important to explore the role of early modern common law in the production of "gender" itself as an organizing category that is distinct from the body and from "sex."

Although many individuals today use the words "sex" and "gender" interchangeably, it is generally accepted that "gender" is used to signify the social experience of sex, whereas "sex" refers to the biological characteristics of sex. As Scott $(1988,29)$ notes, the conceptual separation of sex from gender was adopted by American feminists as means of fighting biological determinism and of emphasizing the social dimensions of the discrimination between men and women. In the legal sense, too, it is a generally accepted interpretation in contemporary US jurisprudence that gender refers to the "cultural or attitudinal characteristics distinctive to the sexes," whereas sex refers to 
"physical characteristics" (MacKinnon 2007, 211). However, as Scott (1988, 2), Catharine MacKinnon (2007, 212), and others have argued, the notion that the two sexes are dichotomous and distinct "is more a social idea than a biological fact of sex" (see also J. Butler 1999). This idea can be traced and historicized.

Indeed, as we have seen, the sex/gender division did not exist in eighteenth-century common law, and the judicial classification of sex hinged both on the social experience of sex and on anatomical signs, without a fixed hierarchy or balance between them. Court records demonstrate a legal classification process that tried to determine the legal fact of sex by learning about both private and non-private body parts; about how people behaved, spoke, and were educated; and about the other things that we call "gender" today. Genitals were not always examined, and even when they were, they were not always distinctive. In any case, neither genitals nor behavioral, social, and cultural attributes were conclusive factors in the determination of sex.

The separation and prioritization of body over mind (and medical knowledge over lay knowledge) in the context of hermaphrodite classification from the late eighteenth century is an origin story of sorts for the sex/gender system in common law. As we have seen, the body was an important reference point throughout some of the cases and treatises of hermaphrodites, but it was not treated as being superior to other signs. This finding correlates with Geertje Mak's (2013) argument in Doubting Sex, which explores the historic medico-legal regulation of hermaphrodites in nineteenth-century Europe. Mak suggests three rationales or logics according to which intersex people were classified: the early idea of sex as an "inscription" of social status in the community; sex as a "body" or "physical" sex that was constantly in operation; and the relatively later logic of sex as "self," referring to one's sense of their own sex (225-30). According to Mak, these logics often operated simultaneously and sometimes in contradiction, and the balance between them changed over time.

Mak $(2013,229)$ further argued that the increasing medical access to hermaphroditic bodies was accompanied by a "dislodgement of the person from the body." The medical dissolution of the body from the self, according to Mak, led to a medical "turn inwards" that advanced the hermaphrodite's inner sense of sex in the twentieth century as a classification criterion (232). The typology offered by Mak correlates to some extent with English rationales of sex classification, and it further invites an exploration of the place of "self" expressions of sex in judicial classifications in eighteenth-century England. ${ }^{52}$ What weight was given, for example, to self-testimonies of people with doubtful sex within a judicial process of classification in the early modern era? In his introduction to Herculine Barbin, Michel Foucault (1980, viii) mentions that French civil law permitted hermaphrodites to choose their sex before marriage. Indeed, the

52. Mak's $(2013,228)$ impressive research and conclusions address nineteenth-century continental Europe, but the early rationales she discusses are relevant to the English context as well. One difference between the two works is in the periodization of rationales. Mak, for example, suggests that, although medical experts were called to assist judicial authorities in classifying or reassigning sex, the willingness of people to visit doctors for medical examination of their internal bodies became socially legitimate only after 1870 in France. Accordingly, Mak seems to date that rise of the "body" logic of sex to the last quarter of the nineteenth century. In contrast, this article focuses on the English common law tradition and suggests that some judicial recognition of the superiority of the body began in the late eighteenth century, with the rise of medico-legal science. 
French law is mentioned in historical references. In the 1718 Treatise of Hermaphrodites, Giles (1719) mentioned that "Civil Law does not regard Hermaphrodites as Monsters, it permits them to make a Choice of either of the two Sexes for the Business of Copulation, either in the Capacity of Men or Women." 53 The hermaphrodite was also expected to perform "his part agreeable to nature"; otherwise, he would face punishment for sodomy (Giles 1719). A 1670 song about a hermaphrodite named Mary Jewit implies that this rule may have been practiced in early modern England as well (Male and Female Husband 1670). According to the song, Jewit was raised as a woman, worked as a midwife, and gave her "free consent" to become a man and marry a young maid, whom she had impregnated. ${ }^{54}$

Although it is possible that, for the purpose of marriage, limited choice was given in England as well, it would be misleading to argue that intersex people were free to choose their sex as a rule in early modern times. Such choice was an exception to both English and civil law, which placed decisions about sex classification in the domain of external authorities. Daston and Park $(1985,2-4)$ have argued that the ideal of "free choice" in France as described by Foucault (1980, viii) was likely never a reality. Their analysis suggests that cultural, specialized, and autonomous determinations of sex in ambiguous cases existed at all times in different capacities. In any case, from the sixteenth century onward, French judicial authorities began relying on "outside testimony to determine the hermaphrodite's predominant sex" (Daston and Park 1995, 426). The Anglo-American case demonstrates a similar mix, giving some weight to autonomous knowledge in addition to other (mainly communal) sources of authority.

Although people with doubtful sex were invited to testify in court and share their own life stories, they were not necessarily trusted. In fact, suspicion of such testimony had long been an established principle in legal epistemology; ${ }^{55}$ early modern law of evidence construed self-testimony as self-interested and unreliable, so it was not accepted under the disqualification rule. ${ }^{56}$ This general suspicion of, and distrust in, hermaphrodites' self-presentation and claimed sex are also evident in the portrayal of intersex people as deceivers who were trying to escape debt, escape prison, or engage in immoral sexual acts. ${ }^{57}$ Despite such distrust in what a person said about themselves, the ability

53. Giles (1719) did not cite any authority when granting some formal authority to the hermaphrodite to choose his or her own sex, but a later source written by James Parsons (1741, xxxiv) attributes this rule to the codex of canon and civil law and referred to a seventeenth-century Latin book Quantum ad matrimonium contrahendum, which consolidated opinions of theologians, jurists, doctors, philosophers, and rabbinic opinions.

54. "[F]or since the wench was got with child, they both must married be, To which our Hermophrodite, did give his free, consent: And changing habit for a man, he to the Church straight went." Male and Female Husband 1670. 2000).

55. On the migration of epistemological principles of proof from law to science, see Shapiro 1991,

56. Distrustfulness of self-testimonies can also be seen as an extension of a legal evidentiary rule formalized in the eighteenth-century common law of evidence, according to which a person (plaintiff or defendant) was disqualified from testifying in his or her own interest regarding the outcome of litigation and was ostensibly a perjurer if they did so. This rule started to vanish when the law of evidence moved away from its primary reliance on written evidence and began accepting oral testimonies that could be cross-examined. See Langbein 1996, 1194-96.

57. For a discussion on hermaphrodites as deceivers in the early nineteenth century, see Reis 2009, 23. 
of that person to perform one's claimed sex seemed vital both inside and outside the court.

Eighteenth-century judicial reasoning about sex in many ways supports what Judith Butler (1999) argued in her book Gender Trouble. In pre- and early modern periods, when sex was not yet constructed as an ahistoric, pre-discursive, politically neutral, and natural identifier, the reading and interpretation of sex was overtly bound up with cultural understandings of maleness and femaleness. Justices, witnesses, juries, and legal writers all used a process of circular reasoning that bounced between corporeal and noncorporeal attributes and that was contingent on their own gauge of femininity and masculinity. Intersex people could accordingly perform or "mimic" their chosen sex, and, if they did so convincingly, they could gain access to the desired category.

Perhaps the most striking feature of the life narratives unpacked in intersex people's testimonies is their ingenious use of gender performance, both inside and outside the courtroom. Hall, d'Eon, Boon, and Jones were all reported to use male and female sex presentations interchangeably, depending on life circumstances and their current needs. Hall, for example, was reported to actively alter their gender performance for different reasons (McILwaine 1924, 195); some scholars hypothesized that Hall wore female clothes in order to work as a female sex worker (Reis 2009, 16). Such sex switches were likely highly situational and used to avoid the disadvantages of a strong sexual division of labor. D'Eon was particularly playful with his gender presentation, switching between male and female throughout his life in England and France, either as part of the terms under which he was permitted to return to France or upon his return to England, and in trying to earn money as a feminine-looking fencer (Conlin 2010, 50-51). Some think that he used his sex presentation and his criticism of the King's Bench to profit from the ongoing bets regarding his sex (Wahrman 2004, 33). Constantia Boon and Betty John also showed remarkable resourcefulness in their gender presentations throughout life. Boon presented as a hermaphrodite in London showrooms, as male in order to marry Jones in church, and as female in the courtroom when trying to acquit Jones of the crime of bigamy. Similarly, John apparently lived a rakish life as a man (including going out at night, smoking, getting drunk, and kicking bullies) and took a wife and a mistress, but John then arrived in court as a married woman in order to escape the claimed debt.

It may seem surprising that these individuals were successful in their audacious and repeated reversals in sex presentation, particularly considering the strong sex-based division in legal and civil life at the time. However, as explained in this work, the commonsensical understanding of sex, which did not include a strict boundary between internal and external qualities and between sex and gender, provided opportunities for individuals to transform themselves more simply (that is, by a change of fashion and name) than the medical and scientific approaches. Additionally, the hermaphrodite rule likely impacted their lives only insofar as they "were caught" in some sort of judicial proceeding. Otherwise, it seems that intersex people could fly under the radar and reconstruct their identities repeatedly based on their circumstantial interests. Having such changes go unnoticed (in a legal sense) was likely possible due to looser 
mechanisms of state surveillance, often resulting from a change of residence. ${ }^{58}$ These conditions may have helped make it possible for intersex people to conduct multiple gender crossings and to wear and then strip identities, names, and gender roles as needed or desired.

These ways of engaging with doubtful sex are quite different from contemporary notions of gender, which often refer to it as innate, immutable, and fixed at birth. The notion of gender identity in the context of the eighteenth century is hard to grasp, particularly because the separation between gender and sex is a modern construct that was only beginning to form. Dror Wahrman (2004, 40-45), who historicized the emergence of the modern self in early modern England with regard to gender, race, and class, has argued that the eighteenth century began with an ancient régime of gender and ended with the sex-gender régime. During this transition, gender lost the playful, assumable character that it had maintained in the ancient régime and instead became an element of the self that was innate, essential, and predetermined. Wahrman argues that, as the century progressed, the possibility of choosing a life that transgressed gender roles became less imaginable and more politically threatening and so, by the end of the century, play was replaced with panic. He suggests that this is why d'Eon spent the last thirty or so years of his life committed to one (female) gender presentation challenged only upon his death by dissection and the reports of medical professionals (33).

As presented here, the analysis of this and other cases and legal treatises about hermaphrodites demonstrates that the sex/gender divide-and the superiority of the body over the social characteristics of sex-did not exist in early modern common law jurisprudence. Instead, while both legal and medical classifications of the time sought a certain truth, the commonsense-based legal truth included a degree of uncertainty that the scientific truth wanted to eliminate. The late eighteenth century's legal enchantment with the scientific promise of doubt-free classification, which was fueled by fears about changing social boundaries between the sexes, led to the diminishment of the social experience of sex and to a conceptual separation between sex and gender, which operates until this day in both lay and professional discourses. From that time forward, physical sex diagnosed by a medical expert gradually became seen as a superior criterion for judicial sex classification in cases of doubt. As Wahrman (2004) and Mak (2013) have expounded, gender also transitioned from a presentation to an identity-a constant and innate expression of the self.

\section{CONCLUSION}

During this exciting moment in early modern Anglo-American history, sex was transforming from a legal to a scientific fact. The application of the dominancy rule in courts of the time revealed a strong reliance on communal knowledge brought by witnesses, juries, and the jury of matrons. And because the common law rule did not dictate a hierarchy among different sources of knowledge in the process of sex classification, the reasoning process was left in the hands of judicial fact finders, who

58. As Foucault (1988) described, with time the modern state became intensely involved in the categorization of sex and the inspection of sexuality as a means to control and normalize large populations through governance. 
administered evidence and testimonies idiosyncratically. Although judicial reasoning was, at least in theory, an elevated rationalizing process, it nevertheless relied heavily on the reasoning of lay intuitions held by the commons and the justice himself throughout most of the eighteenth century. As a result, the legal fact of sex in early modern common law did not concentrate on the body but, rather, incorporated social and cultural indications. In contrast, the spread of the Aristotelian model of sex through the ascent of scientific and medical authority outside and inside legal settings, modernized the conceptualization of sex in common law and made it more "true," "immutable," and exclusively "physical." Until this day, and more so in the past decade, the legal fact of sex is in flux. Courts, administrators, legislators, and policy makers attempt to manage mounting challenges to ideas embedded in the modernized view of sex such as its immutability, stability, and exclusively physical nature. Indeed, while the early modern view of sex in common law encompassed the lived experience of sex, the modern concept of sex in common law usually separates the physical aspects of sex (sex) from social/behavioral/cultural ones (gender).

The inclusion of what we today call gender as part of the legal fact of sex in early modern common law does not mean that self-authority was stronger then, yet gender transformations were feasible and evident. Even though intersex people themselves for the most part had no formal authority in these processes of sex classification, they nevertheless demonstrated strategic presentations of sex/gender based on situational interests. Talent and mastery in performing the attributes of the sexes could help intersex people cross between sex categories as they needed or wanted and in legal settings as well. The individuals portrayed in this article did so, executing resourceful and adventurous transitions between genders depending on the advantages and disadvantages awaiting them in a sex-based legal apparatus.

A final important insight is that law played a role in legitimating the invasion into hermaphroditic bodies. As we saw, the bodies of people with doubtful sex were closely examined by community members and physicians under what seem to be coercive conditions. Although these investigations were not directly commissioned by the court, the strong division between the sexes (as entrenched in laws and doctrines) motivated independent examinations by those who wanted to ensure that the laws were not breached. When bodily examinations of hermaphrodites were removed from the commons and transferred to experts, a new kind of medical invasion began to take place. On the road from Douglas's public experiment on Boon to contemporary, nonconsensual sex assignment surgeries on children with differences in sex development, the violation of bodily autonomy has been legitimized and sustained by legal apparatuses from constitutional to private law. ${ }^{59}$ This article sheds light on the legal affirmation of communal and medical aggressiveness toward hermaphroditic bodies throughout history. Whereas the law purports to merely identify reality that exists independent of its observations, this article illustrates how law has actively participated in producing that reality. It has submerged the law-culture-nature divide and exposed a set of silent authorities that are working to carry the conceptual male-female binary and the communal and professional practices that support it.

59. See generally Hermer 2002; Tamar-Mattis 2006; Sudai 2018. 


\section{REFERENCES}

Ashton, John. 1898. The History of Gambling in England. 19th-Century Legal Treatises. London: Duckworth.

Binhammer, Katherine. 2010. "Accounting for the Unaccountable: Lesbianism and the History of Sexuality in Eighteenth-Century Britain." Literature Compass 7, no. 1: 1-15. https://doi.org/ 10.1111/j.1741-4113.2009.00668.x.

Blackstone, William. 1753. Commentaries on the Laws of England. Online Library of Liberty. https://oll. libertyfund.org/title/sharswood-commentaries-on-the-laws-of-england-in-four-books-2-vols.

Boorstin, Daniel J. 1996. The Mysterious Science of the Law: An Essay on Blackstone's Commentaries Showing How Blackstone, Employing Eighteenth Century Ideas of Science, Religion, History, Aesthetics, and Philosophy, Made of the Law at Once a Conservative and a Mysterious Science. Chicago: University of Chicago Press.

Bracton, Henry. 1968. On the Laws and Customs of England. Cambridge: Selden Society and the Belknap Press of Harvard University Press.

—. N.d. "Bracton Online Home Page." Harvard Law School Library. http://amesfoundation.law. harvard.edu/Bracton/.

Bracton, Henry, and Travers Twiss. 2012. Henrici De Bracton De Legibus Et Consuetudinibus Angliæ. Cambridge, UK: Cambridge University Press.

Brogan, Stephen. 2010. "A 'Monster of Metamorphosis': Reassessing the Chevaliers/Chevaliere d'Eon's Change of Gender." In The Chevalier D'eon and His Worlds: Gender, Espionage and Politics in the Eighteenth Century, edited by Simon Burrows, Jonathan Conlin, Russell Goulbourne, and Valerie Mainz, 81-97. London: Continuum.

Brown, Kathleen. 1995. 'Changed ... into the Fashion of Man': The Politics of Sexual Difference in a Seventeenth-Century Anglo-American Settlement." Journal of the History of Sexuality 6, no. 2: 171-93.

Burrows, Simon, Jonathan Conlin, Russell Goulbourne, and Valerie Mainz, eds. 2010. The Chevalier D'eon and His Worlds: Gender, Espionage and Politics in the Eighteenth Century, 81-97. London: Continuum.

Butler, Judith. 1999. Gender Trouble: Feminism and the Subversion of Identity. New York: Routledge. Butler, Sara M. 2019. "More Than Mothers: Juries of Matrons and Pleas of the Belly in Medieval England." Law and History Review 37, no. 2: 353-96. https://doi.org/10.1017/ S0738248018000664.

Capp, Bernard. 2009. "Bigamous Marriage in Early Modern England." Historical Journal 52, no. 3 : 537-56.

Chambers, Ephraim. 1741. Cyclopaedia, or, An Universal Dictionary of Arts and Sciences. Vol. 2. London: Printed for J. F. and C. Rivington.

Cheselden, W. 1722. The Anatomy of the Humane Body, with XXXI Copper-Plates. 2nd ed. London: Printed by S. Collins, and sold by James Knapton, John Sprint, William Taylor, John Senex, William and John Innys, John Osborn, and John Noon.

Clark, Anna. 1998. "The Chevalier d'Eon and Wilkes: Masculinity and Politics in the Eighteenth Century." Eighteenth-Century Studies 32, no. 1: 19-48.

Cohen. Alfred S. 1999. "Tumtum and Androgynous." Journal of Halacha and Contemporary Society 38: 62-85.

Coke, Edward. 1853. Institutes of the Laws of England; or, A Commentary upon Littleton. Part 1. Philadelphia: Robert H. Small.

—. 1979. Institutes of the Lawes of England. Part 1, 1628 ed. New York: Garland Publishing. https:// catalog.hathitrust.org/Record/009526978.

Comyns, John. 1762. A Digest of the Laws of England: Selden Society Publications and English Legal History. London: Printed by H. Woodfall, and W. Strahan, Law Printers to the King's Most Excellent Majesty; For John Knapton, Thomas Longman, and Robert Horsfield.

Conlin, Jonathan. 2010. "The Strange Case of the Chevalier d'Eon." History Today 60, no. 4: 45-51. 
"Court of Requests." N.d. Encyclopedia Britannica. https://www.britannica.com/topic/Court-ofRequests.

Crawford, Catherine. 1994. "Legalizing Medicine: Early Modern Legal Systems and the Growth of Medico-Legal Knowledge." In Legal Medicine in History, edited by Catherine Crawford and Michael Clark, 89-116. Cambridge, UK: Cambridge University Press.

Da Costa, Palmira Fontes. 2004. "'Mediating Sexual Difference': The Medical Understanding of Human Hermaphrodites in Eighteenth-Century England." In Cultural Approaches to the History of Medicine: Mediating Medicine in Early Modern and Modern Europe, edited by Willem de Blécourt and Cornelie Usborne, 127-47. London: Palgrave Macmillan. https://doi.org/10. 1057/9780230287594_8.

Darr, Orna Alyagon. 2014. "Experiments in the Courtroom: Social Dynamics and Spectacles of Proof in Early Modern English Witch Trials." Law $\mathcal{E}$ Social Inquiry 39, no. 1: 152-75. https://doi.org/10. 1111/lsi.12054.

Daston, Lorraine, and Katharine Park. 1985. "Hermaphrodites in Renaissance France." Critical Matrix: The Princeton Journal of Women, Gender, and Culture 1, no. 5: 1-19.

- 1995. "The Hermaphrodite and the Orders of Nature: Sexual Ambiguity in Early Modern France." GLQ: A Journal of Lesbian and Gay Studies 1, no. 4: 419-38.

. 1998. Wonders and the Order of Nature, 1150-1750. New York: Zone Books.

Dreger, Alice Domurat. 1998. Hermaphrodites and the Medical Invention of Sex. Cambridge, MA: Harvard University Press.

Elrington, C. R. 2004. "Hutton, William (1723-1815), Historian." Oxford Dictionary of National Biography. https://doi.org/10.1093/ref:odnb/14317.

Encyclopaedia Britannica; or, a Dictionary of Arts and Sciences, Compiled upon a New Plan. 1771. Edinburgh: Printed for A. Bell and C. Macfarquhar and sold by C. Macfarquhar.

Fausto-Sterling, Anne. 2000. Sexing the Body: Gender Politics and the Construction of Sexuality. Rev. ed. New York: Basic Books.

Forbes, Thomas R. 1988. "A Jury of Matrons." Medical History 32, no. 1: 23-33.

Foucault, Michel. 1980. Herculine Barbin: Being the Recently Discovered Memoirs of a Nineteenth-Century French Hermaphrodite. New York: Pantheon Books.

- 1988. The History of Sexuality. New York: Vintage Books. 1998. Ethics: Subjectivity and Truth. New York: New Press.

Gallanis, T. P. 1999. "The Rise of Modern Evidence Law." Iowa Law Review 84, no. 3: 499-560.

Garland, Fae, and Mitchell Travis. 2020. "Making the State Responsible: Intersex Embodiment, Medical Jurisdiction, and State Responsibility." Journal of Law and Society 47, no. 2: 298-324. https://doi.org/10.1111/jols.12223.

The Gentleman's Magazine: and Historical Chronicle. 1768. "List of Deaths for 1768."

Gilbert, Geoffrey. 1795. The Law of Evidence, by Lord Chief Baron Gilbert. Dublin: Printed for P. Byrne, J. Moore, W. Jones, and J. Rice.

Gilbert, Ruth. 2002. Early Modern Hermaphrodites: Sex and Other Stories. New York: Palgrave.

Giles, Jacob. 1718. Tractus de Hermaphrodites Or, A Treatise of Hermaphrodites. London: Printed for E. Curll, Fleet Street.

1719. The Laws of Appeals and Murder. London: Printed by Eliz. Nutt, and R. Gosling, (assigns of Edward Sayer, Esq;) for Bernard Lintot, between the Temple-Gates.

Godolphin, John. 1701. The Orphan's Legacy, or, A Testamentary Abridgment: In Three Parts. London: Printed by the assigns of Richard and Edward Atkins for Robert Vincent.

Golan, Tal. 2004. Laws of Men and Laws of Nature: The History of Scientific Expert Testimony in England and America. Cambridge, MA: Harvard University Press.

Gross, Ariela Julie. 2009. What Blood Won't Tell: A History of Race on Trial in America. Cambridge, MA: Harvard University Press.

Guerrini, Anita. 2016. "The Hermphrodite of Charing Cross." In The Uses of Humans in Experiment, edited by Erika Dyck and Larry Stewart, 28-51. Leiden: Brill.

Haney-López, Ian. 2006. White by Law: The Legal Construction of Race. 10th anniversary ed. New York: New York University Press. 
Hermer, Laura. 2002. "Paradigms Revised: Intersex Children, Bioethics and the Law." Annals of Health Law 11: 195-236.

Hutton, William. 1787. Courts of Requests: Their Nature, Utility, and Powers Described, with a Variety of Cases Determined in That of Birmingham. Birmingham: Parson and Rollason.

Iacub, Marcela. 2009. "Gender, Religion, Law." Cardozo Law Review 30, no. 6: 2761-69.

Intersex Society of North America. N.d. "Is a Person Who Is Intersex a Hermaphrodite?" https://isna.org/ faq/hermaphrodite/.

Jackson, W. M. 1794. The New and Complete Newgate Calendar; Or, Villary Displayed in All Its Branches. London: Alex Hogg.

Jasanoff, Sheila. 2018. "Science, Common Sense and Judicial Power in U.S. Courts." Daedalus 147, no. 4: 15-27.

Kendall, Edward Augustus. 1818. An Argument for Construing Largely the Right of an Appellee of Murder, to Insist on Trial by Battle: And Also for Abolishing Appeals: With an Appendix, Containing a Report of a Debate in the House of Commons, on Abolishing Appeal of Murder in the British North American Colonies, Etc. London: Printed by B. R. Howlett, for Baldwin, Cradock, and Joy, and Clarke and Sons.

Kinservik, M. 2008. Sex, Scandal, and Celebrity in Late Eighteenth-Century England. New York: Palgrave Macmillan.

Langbein, John H. 1996. "Historical Foundations of the Law of Evidence: A View from the Ryder Sources." Columbia Law Review 96: 1168-2213.

Langley, Winston, and Vivian C. Fox. 1994. Women's Rights in the United States: A Documentary History. Primary Documents in Americn History and Contemporary Issues Series. Westport, CT: Greenwood Press.

Laqueur, Thomas. 1992. Making Sex: Body and Gender from the Greeks to Freud. Cambridge, MA: Harvard University Press.

Lundberg, Tove, Peter Hegarty, and Katrina Roen. 2018. "Making Sense of 'Intersex' and 'DSD': How Laypeople Understand and Use Terminology." Psychology $\mathcal{E}$ Sexuality 9, no. 2: 161-73. https:// doi.org/10.1080/19419899.2018.1453862.

MacKinnon, Catharine A. 2007. Sex Equality. 2nd ed. New York: Foundation Press.

Macnair, M. 2004. "Sir Comyns John, Judge and Legal Writer." Oxford Dictionary of National Biography. http://doi.org/10.1093/ref:odnb/6050.

The Male and Female Husband. 1670. London: Printed for P. Brooksby at the Golden-ball in West Smithfield.

Mak, Geertje. 2013. Doubting Sex: Inscriptions, Bodies and Selves in Nineteenth-Century Hermaphrodite Case Histories. Manchester: Manchester University Press and Project MUSE.

Matthews, Nancy L. 2008. "Sheppard, William (Bap. 1595, d. 1674), Barrister and Legal Writer." Oxford Dictionary of National Biography. https://doi.org/10.1093/ref:odnb/25349.

McILwaine, H. 1924. Minutes of the Council and General Court of Colonial Virginia. Richmond: n.p.

Morgan, Gwenda, and Peter Rushton. 2005. "Visible Bodies: Power, Subordination and Identity in the Eighteenth-Century Atlantic World." Journal of Social History 39, no. 1: 39-64.

Morning Chronicle and London Advertiser. 1777. July 2.

Murray, Jacqueline. 1990. "On the Origins and Role of 'Wise Women' in Causes for Annulment on the Grounds of Male Impotence." Journal of Medieval History 16, no. 3: 235-49.

Nederman, Cary J., and Jacqui True. 1996. "The Third Sex: The Idea of the Hermaphrodite in Twelfth-Century Europe." Journal of the History of Sexuality 6, no. 4: 497-517.

Nelson, William Edward. 2008. The Common Law in Colonial America. Vol. 1. New York: Oxford University Press.

Norton, Mary Beth. 1997. "Communal Definitions of Gendered Identity in Seventeenth-Century English America." In Through a Glass Darkly: Reflections on Personal Identity in Early America, edited by Ronald Hoffman, Mechal Sobel, and Fredrika Teute, 40-66. Chapel Hill: University of North Carolina Press.

—. 2011. Separated by Their Sex: Women in Public and Private in the Colonial Atlantic World. Ithaca, NY: Cornell University Press. 
Norton, Rictor. 2005. "The Case of Chevalier D'Eon, 1777." In Homosexuality in Eighteenth-Century England: A Sourcebook. 'http://rictornorton.co.uk/eighteen/d'eon.htm.

Oldham, James. 2006. Trial by Jury: The Seventh Amendment and Anglo-American Special Juries. New York: New York University Press.

Olsen, Kirstin. 2017. Daily Life in 18th-Century England. 2nd ed. Westport, CT: Greenwood Press. Oxford English Dictionary Online. N.d.a. "Epicene, Adj. and n."

—. N.d.b. "Hermaphrodite, n. and Adj."

- N.d.c. "Member, n. and Adj."

- N.d.d. "Purchase, n."

Parsons, James. 1741. A Mechanical and Critical Enquiry into the Nature of Hermaphrodites. London: J. Walthoe.

—. 1751. "A Letter to the President, Concerning the 'Hermaphrodite' Shewn in 'London." Philosophical Transactions 47: 142-45.

Pitcher, E. W. 1983. "A Reconsideration of Magazine Serials in The Town and Country Magazine." The Library 65, no. 1: 44-52.

Poppesco, Bassile. 1875. Hermaphroditism, from a Medico-Legal Point of View. Chicago: W. B. Keen, Cook \& Company.

The Post Man, and the Historical Account. 1714. December 7.

Reis, Elizabeth. 2009. Bodies in Doubt: An American History of Intersex. Baltimore, MD: Johns Hopkins University Press.

Riddell, William Renwick. 1918. "Common Law and Common Sense." Yale Law Journal 27, no. 8: 993-1007.

Scott, Joan Wallach. 1988. Gender and the Politics of History. New York: Columbia University Press.

Shammas, Carole. 1987. "English Inheritance Law and Its Transfer to the Colonies." American Journal of Legal History 31, no. 2: 145-63.

Shapiro, Barbara J. 1991. "Beyond Reasonable Doubt" and "Probable Cause": Historical Perspectives on the Anglo-American Law of Evidence. Berkeley: University of California Press.

- 2000. A Culture of Fact: England, 1550-1720. Ithaca, NY: Cornell University Press.

Sharpe, Andrew N. (Alex) 2009. "England's Legal Monsters." Law, Culture and the Humanities 5, no. 1: 100-130. https://doi.org/10.1177/1743872108096865.

- (Alex) 2010. Foucault's Monsters and the Challenge of Law. London: Routledge and Cavendish, Taylor \& Francis Group.

Sheppard, William. 1656. An Epitome of All the Common $\mathcal{G}$ Statute Laws of This Nation Now in Force Wherein More Then Fifteen Hundred of the Hardest Words or Terms of the Law Are Explained, and All the Most Useful and Profitable Heads or Titles of the Law by Way of Common Place, Largely, Plainly and Methodically Handled: With an Alphabetical Table. London: Printed for W. Lee, D. Pakeman, F. Wright, H. Twyford, G. Bedell, Tho. Brewster, Ed. Dod, and F. Place.

A Short Sketch of Some Remarkable Occurrences during the Residence of the Late Chevalier d'Eon in England. Selected from a Variety of Public Documents. 1810. London: Printed for John Booth.

Society of Gentlemen. 1754. A New and Complete Dictionary of Arts and Sciences; Comprehending All the Branches of Useful Knowledge, with Accurate Descriptions as Well of the Various Machines, Instruments, Tools, Figures, and Schemes Necessary for Illustrating Them, as of The Classes, Kinds, Preparations, and Uses of Natural Productions, Whether Animals, Vegetables, Minerals, Fossils, or Fluids; Together with The Kingdoms, Provinces, Cities, Towns, and Other Remarkable Places throughout the World. London: W. Owen, at Homer's Head, in Fleet Street.

Stretton, Tim, and K. J. Kesselring. 2013. Married Women and the Law: Coverture in England and the Common Law World. Montreal and Kingston: McGill-Queen's University Press.

Sudai, Maayan. 2018. "Revisiting the Limits of Professional Autonomy: The Intersex Rights Movement's Path to De-Medicalization." Harvard Journal of Law $\mathcal{E}$ Gender 41, no. 1: 1-54.

Swain, Warren. 2015. "Contract Law, Illegality and Public Policy." In The Law of Contract 16701870, 231-49. Cambridge, UK: Cambridge University Press. https://doi.org/10.1017/ CBO9781139629324.010.

Tamar-Mattis, Anne. 2006. "Exceptions to the Rule: Curing the Law's Failure to Protect Intersex Infants." Berkeley Journal of Gender, Law EF Justice 21: 59-254. 
The Town and Country Magazine, or, Universal Repository of Knowledge, Instruction, and Entertainment. 1769. Vol 3. https://catalog.hathitrust.org/Record/000493943.

The Tyburn Chronicle: Or, Villainy Display'd in All Its Branches. Containing an Authentic Account of the Lives, Adventures, Tryals, Executions, and Last Dying Speeches of the Most Notorious Male Factors. Of All Denominations, Who Have Suffered for Bigamy, Forgeries, Highway-Robberies, HouseBreaking, Murders, Perjury, Piracy, Rapes, Riots, Sodomy, Starving, Treason, And Other the Most Enormous Crimes. 1768. Vol. 2. London: J. Cooke, at Shakespeare's Head, in Pater-Noster Row.

VanBurkleo, Sandra F. 2001. "Belonging to the World": Women's Rights and American Constitutional Culture. New York: Oxford University Press.

Vaughan, Alden T. 1978. "The Sad Case of Thomas(Ine) Hall." Virginia Magazine of History and Biography 86, no. 2: 146-48.

W. J. (Barrister at Law). 1710. The Common and Statute Law of England, Concerning Trials in HighTreason, Misprision of Treason, and in All Other Crimes and Offences Relating to the Crown; Briefly Collected out of the Common and Statute Law-Books and Trials Relating to That Subject. London: John Nutt, assignee of Edward Sayer Esq, for John Walthoe.

Wagner, Peter. 1982. "The Pornographer in the Courtroom: Trial Reports about Cases of Sexual Crimes and Delinquencies as a Genre of Eighteenth-Century Erotica." In Sexuality in Eighteenth-Century Britain, edited by Paul-Gabriel Boucé, 120-40. Manchester: Manchester University Press.

Wahrman, Dror. 2004. The Making of the Modern Self: Identity and Culture in Eighteenth-Century England. New Haven, CT: Yale University Press. http://www.loc.gov/catdir/toc/ecip0414/ 2004001544.html.

Wharton, John Jane Smith. 1987. The Law Lexicon: Or, Dictionary of Jurisprudence: Explaining All the Technical Words and Phrases Employed in the Several Departments of English Law, Including Also the Various Legal Terms Used in Commercial Transactions, together with an Explanatory as Well as Literal Translation of the Latin Maxims Contained in the Writings of the Ancient and Modern Commentators. London. Spinelli's Law Library Reference Shelf.

Wraxall, Lascelles. 1861. Criminal Celebrities: A Collection of Memorable Trials. London: W. Kent and Company.

Zaher, Claudia. 2002. "When a Woman's Marital Status Determined Her Legal Status: A Research Guide on the Common Law Doctrine of Coverture." Law Library Journal 94, no. 3: 459-800. 